University of South Florida

DIGITAL COMMONS Digital Commons @ University of @ UNIVERSITY OF SOUTH FLORIDA South Florida

\title{
Analysis of Transit Contracting Models and Proper Incentives for Long-Term Success
}

CUTR

Follow this and additional works at: https://digitalcommons.usf.edu/cutr_nctr

\section{Recommended Citation}

"Analysis of Transit Contracting Models and Proper Incentives for Long-Term Success," National Center for Transit Research (NCTR) Report No. CUTR-NCTR-RR-2013-11, Center for Urban Transportation Research, University of South Florida, 2014.

DOI: https://doi.org/10.5038/CUTR-NCTR-RR-2013-11

Available at: https://scholarcommons.usf.edu/cutr_nctr/92

This Technical Report is brought to you for free and open access by the National Center for Transit Research (NCTR) Archive (2000-2020) at Digital Commons @ University of South Florida. It has been accepted for inclusion in Research Reports by an authorized administrator of Digital Commons @ University of South Florida. For more information, please contact digitalcommons@usf.edu. 


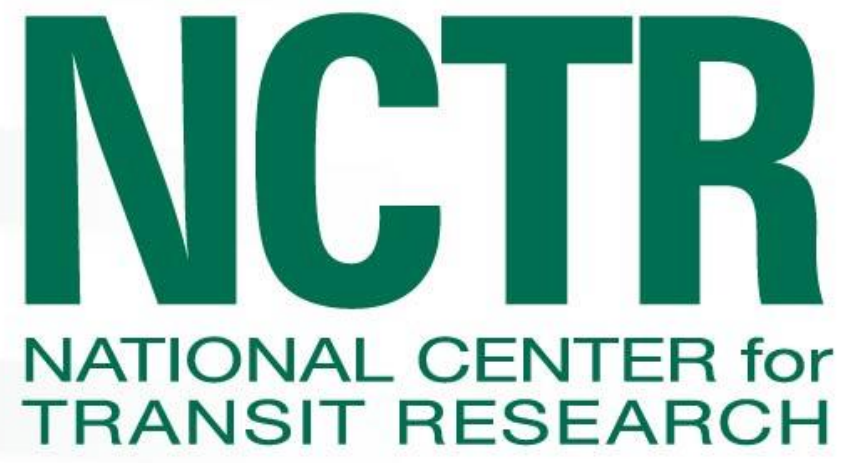

\section{Analysis of Transit Contracting Models and Proper Incentives for Long-Term Success}

\section{November 2013}

PROJECT NO.

FDOT BDK85-977-47

Final Report

PREPARED FOR

Florida Department of Transportation 


\section{Analysis of Transit Contracting Models and Proper Incentives for Long-Term Success}

FDOT BDK85-977-47

Prepared for:

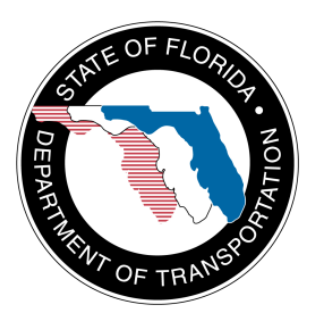

Florida Department of Transportation Ed Coven, Project Manager

\section{Prepared by:}

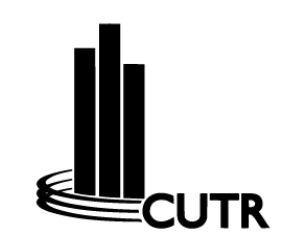

USF Center for Urban Transportation Research

Janet L. Davis, Associate in Research

Stephen L. Reich, Associate in Research

Final Report

November 2013 


\section{Disclaimer}

The contents of this report reflect the views of the authors, who are responsible for the facts and the accuracy of the information presented herein. This document is disseminated under the sponsorship of the U.S. Department of Transportation University Transportation Centers Program and the Florida Department of Transportation in the interest of information exchange. The U.S. Government and the Florida Department of Transportation assume no liability for the contents or use thereof. 


\section{Metric Conversion}

\begin{tabular}{|c|c|c|c|c|}
\hline SYMBOL & WHEN YOU KNOW & MULTIPLY BY & TO FIND & SYMBOL \\
\hline \multicolumn{5}{|c|}{ LENGTH } \\
\hline in & inches & 25.4 & millimeters & $\mathrm{mm}$ \\
\hline $\mathrm{ft}$ & feet & 0.305 & meters & $\mathrm{m}$ \\
\hline yd & yards & 0.914 & meters & $\mathrm{m}$ \\
\hline mi & miles & 1.61 & kilometers & $\mathrm{km}$ \\
\hline \multicolumn{5}{|c|}{ VOLUME } \\
\hline fl oz & fluid ounces & 29.57 & milliliters & $\mathrm{mL}$ \\
\hline gal & gallons & 3.785 & liters & $\mathrm{L}$ \\
\hline $\mathrm{ft}^{3}$ & cubic feet & 0.028 & cubic meters & $\mathrm{m}^{3}$ \\
\hline$y d^{3}$ & cubic yards & 0.765 & cubic meters & $m^{3}$ \\
\hline \multicolumn{5}{|c|}{ NOTE: volumes greater than $1000 \mathrm{~L}$ shall be shown in $\mathrm{m}^{3}$} \\
\hline \multicolumn{5}{|c|}{ MASS } \\
\hline oz & ounces & 28.35 & grams & $\mathrm{g}$ \\
\hline lb & pounds & 0.454 & kilograms & $\mathrm{kg}$ \\
\hline $\mathbf{T}$ & short tons $(2000 \mathrm{lb})$ & 0.907 & $\begin{array}{c}\text { megagrams } \\
\text { (or "metric ton") }\end{array}$ & $\mathrm{Mg}$ (or "t") \\
\hline \multicolumn{5}{|c|}{ TEMPERATURE (exact degrees) } \\
\hline${ }^{\circ} \mathbf{F}$ & Fahrenheit & $\begin{array}{c}5(F-32) / 9 \\
\text { or }(F-32) / 1.8\end{array}$ & Celsius & ${ }^{\circ} \mathrm{C}$ \\
\hline
\end{tabular}




\section{Technical Report Documentation}

\begin{tabular}{|c|c|c|c|c|}
\hline 1. Report No. & \multicolumn{2}{|c|}{ 2. Government Accession No. } & \multicolumn{2}{|l|}{ 3. Recipient's Catalog No. } \\
\hline \multicolumn{3}{|c|}{$\begin{array}{l}\text { 4. Title and Subtitle } \\
\text { Analysis of Transit Contracting Models and Proper Incentives for Long-Term } \\
\text { Success }\end{array}$} & \multicolumn{2}{|l|}{$\begin{array}{l}\text { 5. Report Date } \\
\text { November } 2013\end{array}$} \\
\hline \multicolumn{3}{|l|}{$\begin{array}{l}\text { 7. Author(s) } \\
\text { Janet L. Davis, Stephen L. Reich }\end{array}$} & \multicolumn{2}{|c|}{$\begin{array}{l}\text { 8. Performing Organization Report No. } \\
\text { NCTR 77952-00/BDK85-977-47 }\end{array}$} \\
\hline \multicolumn{3}{|c|}{$\begin{array}{l}\text { 9. Performing Organization Name and Address } \\
\text { National Center for Transit Research } \\
\text { Center for Urban Transportation Research (CUTR) } \\
\text { University of South Florida } \\
4202 \text { East Fowler Avenue, CUT100 } \\
\text { Tampa, FL 33620-5375 }\end{array}$} & \multicolumn{2}{|l|}{$\begin{array}{l}\text { 11. Contract or Grant No. } \\
\text { FDOT BDK85-977-47 }\end{array}$} \\
\hline \multicolumn{3}{|c|}{$\begin{array}{l}\text { Research and Innovative Technology Administration } \\
\text { U.S. Department of Transportation } \\
\text { Mail Code RDT-30 } \\
1200 \text { New Jersey Ave. SE, Room E33 } \\
\text { Washington, D.C. } 20590-0001\end{array}$} & \multicolumn{2}{|l|}{ 14. Sponsoring Agency Code } \\
\hline \multicolumn{5}{|l|}{$\begin{array}{l}\text { 15. Supplementary Notes } \\
\text { FDOT Project Manager: Ed Coven }\end{array}$} \\
\hline \multicolumn{5}{|c|}{$\begin{array}{l}\text { 16. Abstract } \\
\text { As transit systems are being challenged to operate in the most cost-effective manner, and budgets are being tightened and demand } \\
\text { for services increases, there has been renewed interest in the area of contracting for fixed route service in the United States (U.S.). } \\
\text { Researchers were tasked to inventory and synthesize previous work in the area of types of transit operating contracts in the U.S. and } \\
\text { Europe, assess the benefits and drawbacks of each general approach, and develop situational guidance for Florida Department of } \\
\text { Transportation (FDOT) to help determine if a particular model could be appropriately considered. The investigation began with a } \\
\text { review of the literature. Using the National Transit Database for 2011, transit service contracting practices in five states were } \\
\text { reviewed, focusing on the monetary nature of the contractual relationship between the agency and the contractor. Specific contracts } \\
\text { awarded were reviewed to compare and contrast operating parameters outlined in the contracts in terms of assignment, } \\
\text { responsibility, and oversight. Researchers turned to individual transit agencies to explore lessons learned from their contracting } \\
\text { experience, providing valuable insight not only for agencies considering contracting some or all service for the first time, but also for } \\
\text { agencies interested in improving their existing contractual relationships. A contracting decision tree is illustrated, and several } \\
\text { strategies to improve service in-house are detailed for agencies that decide to forego contracting. In order to meet the challenges of } \\
\text { today's economy, transit agencies must understand and assess the benefits and drawbacks of each general approach to contracting } \\
\text { for transit service. }\end{array}$} \\
\hline \multicolumn{2}{|c|}{$\begin{array}{l}\text { 17. Key Words } \\
\text { transit contracting, delegated management contract, fixed-price } \\
\text { transit contract, transit contract performance metrics }\end{array}$} & \multicolumn{3}{|c|}{$\begin{array}{l}\text { 18. Distribution Statement } \\
\text { No restrictions }\end{array}$} \\
\hline $\begin{array}{l}\text { 19. Security Classif. (of this report) } \\
\text { Unclassified }\end{array}$ & \begin{tabular}{l|l} 
20. Security Clas \\
Unclassified
\end{tabular} & his page) & $\begin{array}{l}\text { 21. No. of Pages } \\
56\end{array}$ & 22. Price \\
\hline
\end{tabular}




\section{Executive Summary}

Florida's transit systems, like those nationally, are being challenged to operate in the most cost-effective manner while maintaining a high level of effectiveness as budgets are tightened and demand for services intensifies. There has been renewed interest in contracting for fixed route service in the United States (U.S.). The development of a recent request for proposals for the operation of a Florida transit system raised several issues related to the construction of transit operating agreements. Issues surfaced surrounding a perceived or real tendency for U.S. agencies to be overly prescriptive in contract terms and conditions, which may be stifling the flexibility of private operating entities to employ creative means to offer more value and enhanced service to the public.

The Florida Department of Transportation (FDOT) asked the National Center for Transit Research (NCTR) at the University of South Florida (USF) to inventory and synthesize previous work in the area of types of transit operating contracts in the U.S. and Europe, assess the benefits and drawbacks of each general approach to contracting for transit service, and develop situational guidance for FDOT to help determine if a particular model may be appropriately considered. FDOT also asked researchers to provide findings to Florida's transit operators; however, researchers were expressly precluded from providing prescriptive contracting approaches for local operating decisions.

Contracting with private service providers for the management, operation, and maintenance of transit services has become an acceptable business practice within the transit industry. Based on the results of a recent survey on the subject of contracting by the U.S. Government Accountability Office (GAO) Report to Congressional Committees, Public Transit: Transit Agencies' Use of Contracting to Provide Service, published in 2013 (GAO-13-782), contracting is a common way to provide transit services, with about 61 percent of the 463 transit agencies that responded to the survey indicating they contract some or all operations and services. The report findings are consistent with information gleaned from a literature review conducted in the initial phase of the current research project.

In the U.S., public transit agencies use contracting to procure the services of a private firm through a competitive bid process. The contracted service may be for a portion of the system, such as a bus route, or for system-wide management. The transit agency maintains ownership of the service and authority over setting policies, such as fares and schedules. Private contractors compete to provide transit services, and the agency receives the benefits of competition as prospective bidders offer their best possible price to win the contract. While contracting can be called privatization, in that the service is operated by a private provider through a contractual relationship, the U.S. system contrasts with full privatization efforts, such as those in the United Kingdom and Europe, where private firms own and operate public transit service (Wachs, Frick, and Taylor 2008).

As acceptance of contracting public transit service has grown, the scope of the contractual arrangements between transit agencies and service providers has been somewhat redefined. Typical transit contracts include responsibility for management as well as services that incorporate operations and/or maintenance. Private providers recently introduced a new type of contracting, which they refer 
to as delegated management. Delegated management contracts, which have been used in Europe for a number of years, expand the role of the private operator in the management and operation of the agency, in that all agency functions are delegated to the contractor. In Europe, delegated management contracts include the caveat that, under the arrangement, the contractor shares in the revenue risk. While labels such as management, operations, and delegated management are used to describe the service to be provided pursuant to the contract, the labels fall short of identifying the nature of the contractual arrangement between the agency and private service provider.

Two rather extensive surveys of transit agency managers, the Transportation Research Board's (TRB) Special Report 258, Contracting for Bus and Demand-Responsive Transit Services, published in 2001, and the GAO Report (GAO-13-782) published in 2013, provide a wealth of information concerning the reasons that transit agencies contract service. The most common reason for transit agencies to contract service was to improve operational cost-efficiency, followed by the desire to take advantage of resources available to private contractors that would enhance the agency's capability to start new service or expand existing service. Other reasons for contracting included flexibility in how services are provided, the ability to minimize public employment and unionization, and politics.

Transit agencies' primary reason to retain service in-house was to maintain control. Some agencies questioned if contracting was cost-effective, particularly when the contractor was required to maintain accountability and service quality at a level acceptable to the agency. A number of agencies saw no reason to change, while others cited a lack of competition and union contracts as barriers to contracting service.

Using the National Transit Database (NTD) for 2011, transit service contracting practices in five states were reviewed, focusing on the monetary nature of the contractual relationship between the agency and the contractor, to provide insight into how a contractor is paid for service. A number of the agencies that purchased service from multiple providers engaged in differing monetary arrangements with the providers. Agencies in one of the states frequently provided assistance with costs associated with fuel, tires, and other materials and supplies. The majority of agencies compensated the service provider based on a negotiated rate per unit of service delivered (fixed fee), and gave, sold, loaned, or leased vehicles to the seller for below market value. It was not uncommon for an agency to lease its maintenance facility to the seller. Use of cash reimbursement of some of the seller's operating deficit was reported in several states, as was reimbursement of the seller's entire operating deficit. Two contractual relationships fell outside of the common parameters.

Specific contracts awarded by the City of Petaluma in California (Transit Services), New Orleans Regional Transit Authority in Louisiana (Delegated Management), Jefferson Parish in Louisiana (Management \& Operations of Public Transportation Services), Nassau County in New York (Delegated Management), and Escambia County in Florida (Transit Management) were reviewed to compare and contrast operating parameters outlined in the contracts in terms of assignment, responsibility, and oversight.

Overall, the contracts shared a number of similarities despite the label assigned to the contractual agreement. In each contract, the contractor was defined as an independent contractor. Pursuant to the 
contracts, all agencies supplied revenue vehicles and provided facilities to the contractor for the contractor's use. All contracts assigned responsibility for the condition of equipment and maintenance of vehicles to the contractor, and all contractors were required to provide drivers, supervisors, and personnel for all classifications.

All contractors were responsible for labor negotiations, fare collection and reconciliation, and for the provision of safety and security. All contractors reported to the agency on a monthly basis, at a minimum, and were responsible for FTA/NTD reporting, ensuring compliance with a drug-free workplace, providing all software and hardware, providing customer information service, and managing customer complaints. All contractors, with the exception of one, were required to provide marketing and advertising.

In terms of dissimilarities, the terms of the contracts ranged from three to five years and differed in the length of the renewal term and authorization for renewal. The descriptions of the contract services varied as well. Circumstances allowing renegotiation of the unit cost also varied from contract to contract. Responsibility for service plan development, fare policy, and hours of service was assigned to the contractor in three of the contracts; however, in cases where the contractor was responsible for development, final authority for approval rested with the agency. Responsibility for contract compliance and mandatory personnel, as identified within the contract, varied from agency to agency, as did requirements related to fare box recovery.

Liquidated damages were contained in three of the contracts. In two agency contracts, liquidated damages were primarily operations-related, while liquidated damages in the third contract were vehicle maintenance-related. As an incentive, one contractor could earn up to $\$ 500$ per quarter for increased ridership of greater than 10 percent over the average of the past two quarters.

Performance measures contained in each of the contracts also varied between agencies, regardless of the nature of the agreement. Three contracts incorporated performance metrics common within the transit industry-on-time performance, accident frequency, and ridership growth. One contract required the contractor to certify quarterly on-time performance of at least 90 percent, while another required the contractor to submit a plan to increase ridership at least 10 percent within the first year of the contract. One contract included a variety of operations and maintenance metrics, such as miles between road calls, missed and late trips, pass sales, wheelchair boardings, drug and alcohol testing, and driver-related training and evaluations. Two contracts measured customer satisfaction.

One contract identified performance metrics related to cost that included cost per mile, revenue per mile, and percent of miles at 100 percent recovery, and another required that the contractor seek to reduce the operating cost per hour by 25 percent throughout the term of the contract. One contract identified two technology-related performance measures that required the contractor to implement rider technology within three months and to establish and maintain a GIS layer for all routes, stops, benches, and shelters within six months. 
A single contract required the contractor to invest in-house technical resources for development or financing of new or expanded rail service, invest in the agency's infrastructure, provide services to seek public funding at local, state, and federal levels, and provide a national Emergency Response Team in the event of a natural disaster.

At a minimum, all contractors were compensated through a fixed fee arrangement paid in monthly installments. A single agency reimbursed the contractor for all operating expenses incurred, in addition to the payment of the fixed fee for management services. Three agencies paid a variable fee based on a negotiated rate per platform hour, in addition to the monthly fixed fee.

Researchers turned to individual transit agencies to explore lessons learned from their contracting experience. Understanding problems and successes encountered by transit agencies currently engaged in contracting provided valuable insight, not only for agencies considering contracting some or all service for the first time, but also for agencies interested in improving their existing contractual relationships with service providers. While most lessons learned were derived from anecdotal accounts, rather than from extensive study of an agency's operating practices, they proved to be valuable by simply identifying problems and issues encountered in the contracting process.

Tailoring a proposal to meet an agency's needs eliminated difficulties that required rebidding the contract. Conducting a detailed cost analysis prior to awarding a new contract or extending an existing contract produced a level of confidence concerning the viability of a low bid and the cost-effectiveness of an extension. Monitoring contractor performance yielded improved customer service and ensured compliance with service standards.

A number of agencies returned to public management to reduce costs, achieve direct accountability, and gain flexibility in service quality and cost. One agency said small contracting companies have been purchased by larger ones, leaving only three competitors. The resulting lack of competition led to less focus on the district goals and more focus on corporate goals. Another agency transitioned to in-house service to eliminate potential disruptions caused by external corporate reorganizations and potential tensions between external corporate goals and agency goals.

Labor issues centered on compensation, work rules, agency control, and working conditions. Agencies can specify compensation packages to attract and retain qualified staff in their contracts, and can consider proposals for compensation in evaluating bids.

A contracting decision tree is illustrated in Figure 1. The decision to contract begins with a cost analysis of current operations, including a route level assessment, followed by cost-efficiency strategy development that incorporates input from peer agencies. After considering the agency's operating environment, an agency is prepared to make the contracting decision.

If an agency elects not to contract service, several strategies may help to improve service in-house. An agency can work to change labor agreements related to work rules and compensation. Changes such as split shift, interlining, and part-time labor provide managers with more flexibility and reduce costs. 
Adjusting vehicle routing and scheduling to reduce non-revenue service, and using efficient vehicles appropriately sized for low ridership routes, enhance system effectiveness and reduce costs.

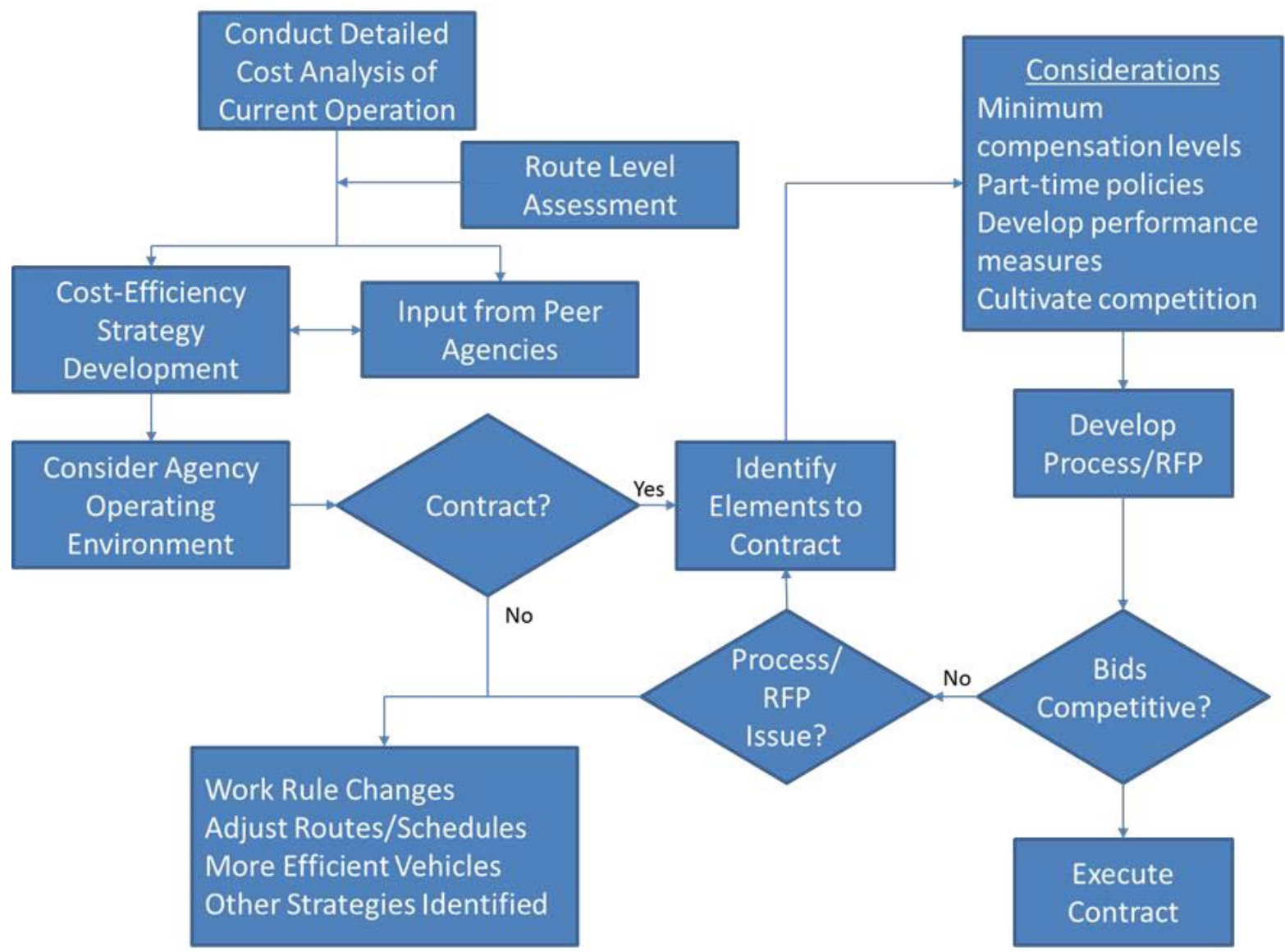

Figure 1 - Contracting Decision Tree

If an agency elects to contract service, elements contracted to achieve agency goals must be identified. An agency can consider providing guidelines or setting minimum compensation levels for private sector employees, examine private contractors' part-time employee policies and the structure of compensation package, develop measures to evaluate contractor performance and service quality, and arrange to monitor the measures. An agency can cultivate a competitive bidding environment to reduce the possibility of one contractor monopolizing service provision.

Contracting for fixed route service is not a "one-size-fits-all approach" (GAO-13-782). It may improve cost-efficiency for some transit agencies, which benefit from the advantages offered by access to better technology and reduced operational expenses. Other agencies, however, find that contracting is actually too costly, preferring to retain direct accountability over service quality and cost, and to avoid the potential complications of external corporate goals. In order to meet the challenges of today's economy, transit agencies must understand and assess the benefits and drawbacks of each general approach to contracting for transit service. This study provides situational guidance to help transit agencies determine if a particular model appropriately supports the agency's efforts to maintain quality service while operating in an efficient manner, and if it fits the agency's goals and expectations. 


\section{Table of Contents}

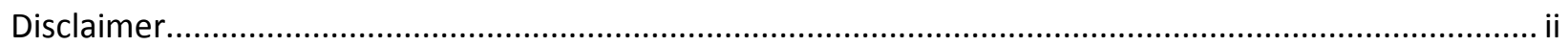

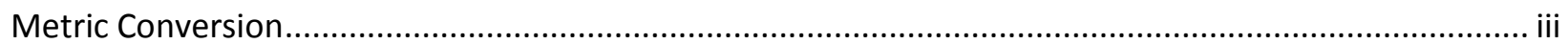

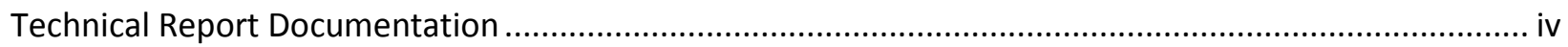

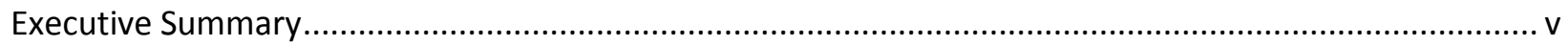

List of Figures

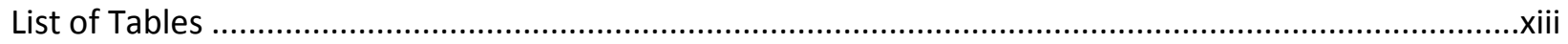

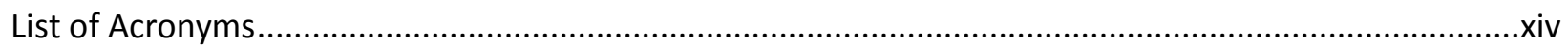

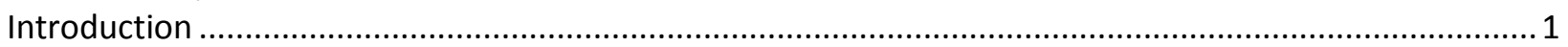

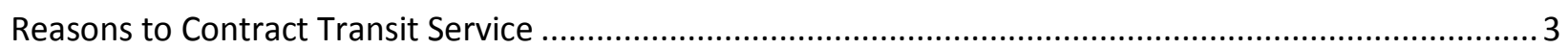

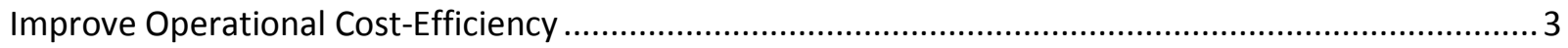

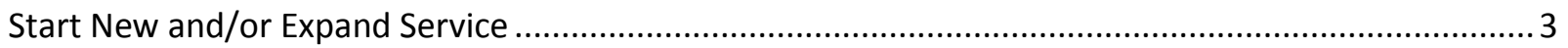

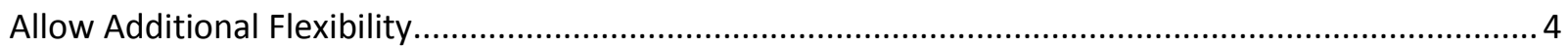

Minimize Public Employment and Unionization ......................................................................... 4

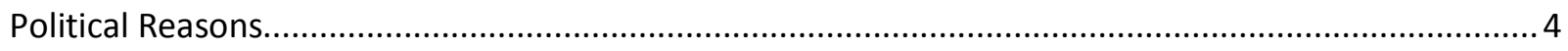

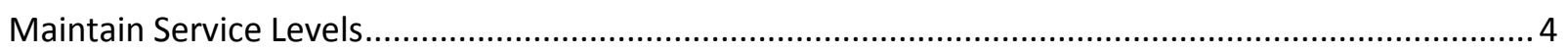

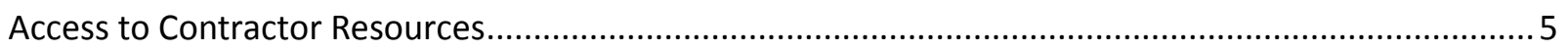

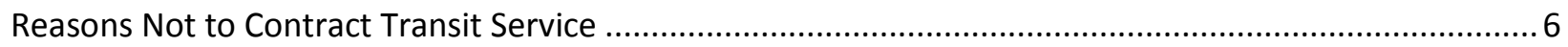

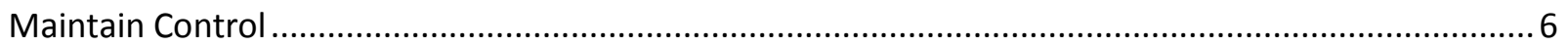

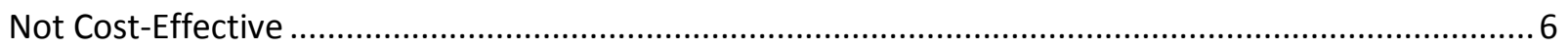

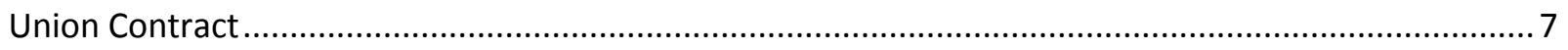

Lack of Competition/Too Few Bidders/Lack of Qualified Firms......................................................... 8

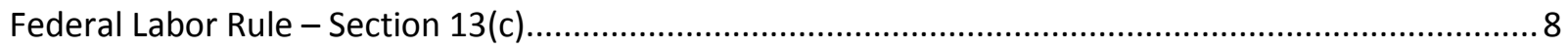

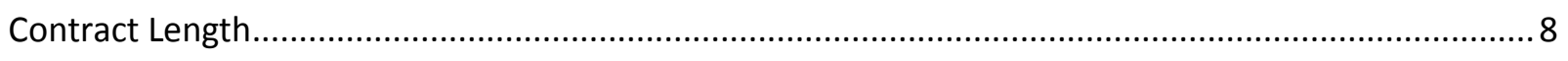

Maintain Accountability/Service Quality ................................................................................. 8

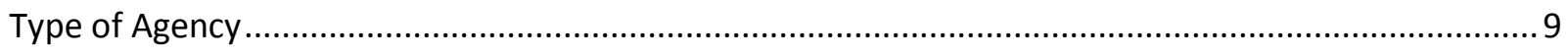

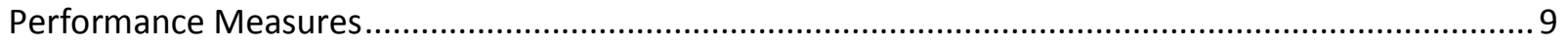

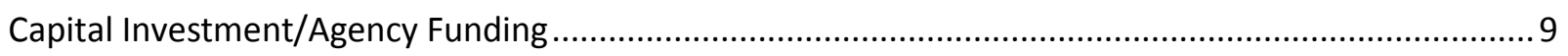

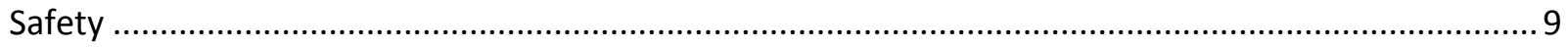

Operating Contracts Executed in Identified Areas.......................................................................... 10

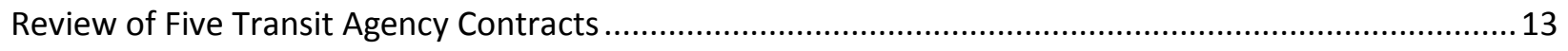

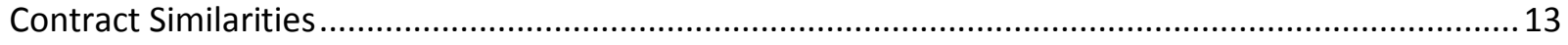

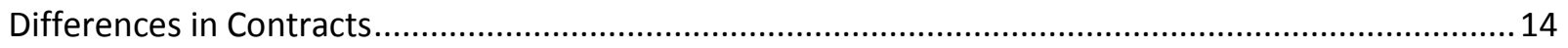

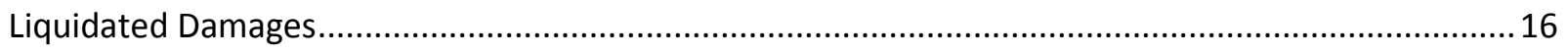

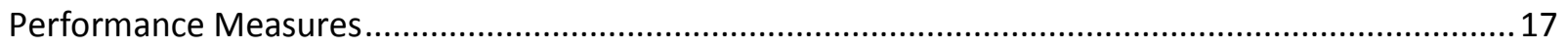

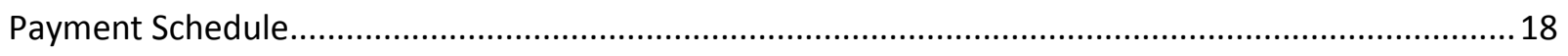

Lessons Learned from Transit Contracting Experience........................................................................ 19

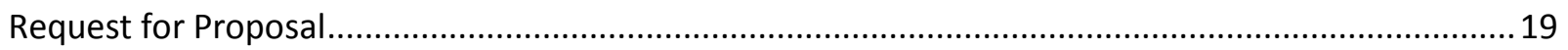

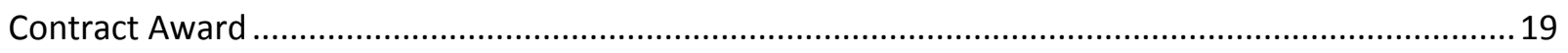

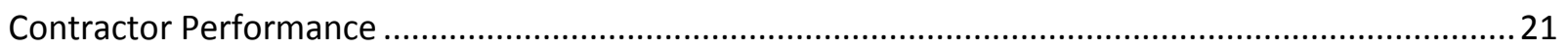

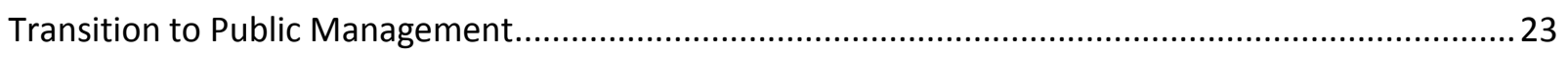

Using Unification to Enhance Cost-Effectiveness and Efficiency ......................................................2 24 


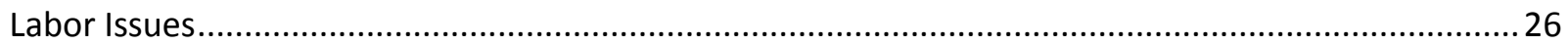

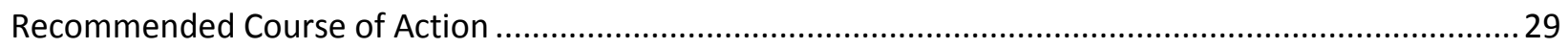

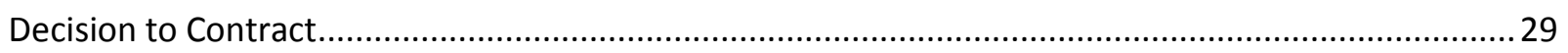

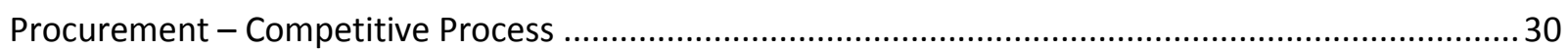

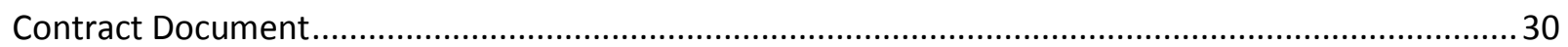

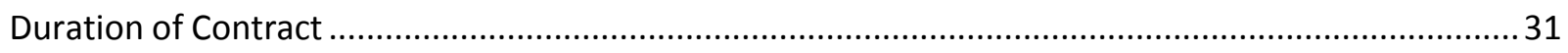

Agency Provision of Equipment - Vehicles ......................................................................

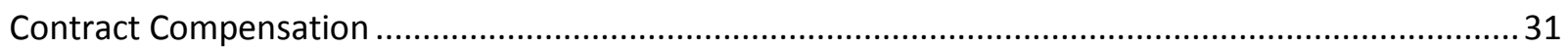

Managing Contract Services.............................................................................................. 32

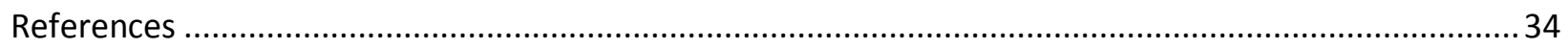

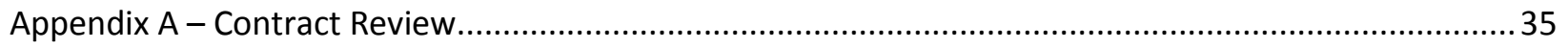




\section{List of Figures}

Figure 1 - Contracting Decision Tree ........................................................................................ ix, 29 


\section{List of Tables}

Table 1 - Monetary Nature of Contractual Relationship - Rail .......................................................... 11

Table 2 - Monetary Nature of Contractual Relationship - Bus .......................................................... 12

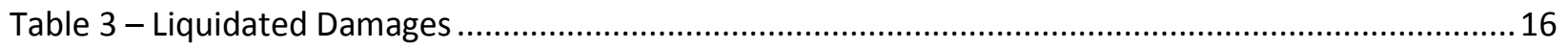

Table 4 - Transit Agency Performance Measures ............................................................................... 17

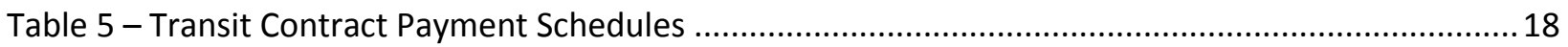

Table 6 - Proposed Wages, Benefits, and New Work Rules ............................................................... 27 


\section{List of Acronyms}

ADA

APTA

ATU

CMP

CPI

DO

FDOT

FTA

FY

GAO

GIS

IGA

MSA

NTD

PT

RFP

RTA

TDP

TRB
Americans with Disabilities Act

American Public Transportation Association

Amalgamated Transit Union

Contract Management Plan

Consumer Price Index

Directly Operated

Florida Department of Transportation

Federal Transit Administration

Fiscal Year

Government Accountability Office

Geographic Information System

Intergovernmental Agreement

Management Services Agreement

National Transit Database

Purchased Transportation

Request for Proposal

New Orleans Regional Area Transit Authority

Transit Development Plan

Transportation Research Board 


\section{Introduction}

The investigation and documentation of practices in contracting for fixed route public transportation service began with a review of the literature, which was delivered to Florida Department of Transportation as "Analysis of Transit Contracting Models and Proper Incentives for Long-Term Success, Task 1 - Literature Review." Researchers focused on exploring variations in contracting not only within the U.S. in comparison with Europe, but also between U.S. agencies. In the U.S., the term contracting out is generally used when a public transit agency procures the services of a private firm through a competitive bid process. The contracted service may be for a portion of the system, such as a bus route, or system-wide. The transit agency typically maintains ownership of the service and authority over setting policies, such as fares and schedules. While contracting can be called, less accurately, privatization, the U.S. system contrasts with full privatization efforts, such as those in the United Kingdom, where private firms own and operate public transit service (Wachs, Frick, and Taylor 2008).

A review of the literature was also undertaken to identify the reasons for which agencies decide to provide service directly and/or to contract service to a private service provider. Transportation service provided directly by an agency, using their employees to supply the necessary labor to operate the revenue vehicles, is classified as directly operated (DO); services provided to a transit agency through a contractual agreement are classified as purchased transportation (PT). Private contractors compete for service, generally through a competitive bid process, and the agency receives the benefits of competition as prospective bidders offer their best possible price to win the contract (Leland and Smirnova 2009).

Reasons for which transit agencies decide to contract service or retain service in-house are detailed in the first section of the report. The most common reason that transit agencies contracted service was to improve operational cost-efficiency, followed by the desire to take advantage of resources available to private contractors that would enhance the agency's capability to start new service or expand existing service. Other reasons for contracting include flexibility in how services are provided, the ability to minimize public employment and unionization, and politics.

Transit agencies' primary reason to retain service in-house was to maintain control. Some agencies questioned if contracting was cost-effective, particularly when the contractor was required to maintain accountability and service quality at a level acceptable to the agency. A number of agencies saw no reason to change, while others cited a lack of competition and union contracts as barriers to contracting service.

Reasons that agencies decide to contract service or provide service in-house are followed by a review of transit service contracting practices in the states of California, Georgia, Louisiana, New York, and Florida. The state practices were examined based on the monetary nature of the contractual relationship between the agency and the service provider to provide insight into how a contractor is paid for service rendered. Specific locations for study were identified based on established contracting practices, which included a new form of transit operating contract, as was the case in New Orleans, Louisiana; Savannah, 
Georgia; and Nassau County, New York. Foothill Transit (San Gabriel and Pomona Valleys, California) was also included for study due to a long history of transit contractual arrangements characterized by a significant shift of typical agency roles and responsibilities to the service provider. A detailed review of the contracting practices, examination of five transit agency contracts, along with a small case study of the New Orleans RTA, and preliminary recommendations on contracting methods used elsewhere that might be appropriate for Florida, were delivered as "Analysis of Transit Contracting Models and Proper Incentives for Long-Term Success, Task 2 - Synthesis of Information."

The summary of operating contracts is followed by a detailed review of commonalities and differences in current transit agency contracts awarded by the City of Petaluma in California, New Orleans Regional Transit Authority in Louisiana, Jefferson Parish in Louisiana, Nassau County in New York, and Escambia County in Florida. Three represent arrangements that require the service provider to "manage, operate, and maintain" transit service, and two are representative of a delegated management model. Each contract contains provisions typically found in government procurement contracts; as a result, general and federal provisions common to all the contracts were excluded from the detailed comparison. The comparison focuses on areas that differentiate agency approaches to contracting in terms of assignment, responsibility, and oversight.

Following the contract review is a summary of lessons learned from today's transit contracting experiences. Brief summaries of transit agency contract-related activities provide insight to transit agencies, regardless of whether they provide service in-house or contract service to a private provider. Issues are related to the request for proposal, contract award, contractor performance, transition to public management, using unification to enhance cost-efficiency, and labor.

The final section of the document outlines a recommended course of action for transit agencies exploring the issue of contracting service, and presents a contracting decision tree to summarize the process. Contract-related activities are reviewed, which include procurement, the contract document, term of the contract, agency provision of vehicles, compensation, and managing contract services. 


\section{Reasons to Contract Transit Service}

The primary reasons that transit agencies contract public transit service were developed from the extensive body of literature on the subject, and are listed below. Each of the reasons is discussed in detail.

- Improve operational cost-efficiency

- Start new and/or expand service

- Allow additional flexibility

- Minimize public employment and unionization

- Political reasons

- Maintain service levels

- Access to contractor resources

\section{Improve Operational Cost-Efficiency}

Transit agency cost savings are derived from three primary areas. First is the difference in wages between the public and private sectors, where the hourly rate of pay for private employees is less than the public agency's labor cost, which often includes a pension and other labor-related fringe benefit costs (in public transit, labor costs represent about $70 \%$ of total costs). Second, lower costs are generated by competition between private bidders for services along with the "threat of competition" to public employee unions. Finally, agencies realize cost savings by contracting for less-efficient services (Wachs, Frick, and Taylor 2008). Because factors such as agency size, the wage gap between bus operators in the public and private sectors, agency type, and the peak-to-base ratio can affect the costefficiency of contracting, an agency must carefully choose the service level to contract based on an adequate assessment of its operating characteristics and conditions (Iseki 2010). In the recently published GAO Report 13-782, factors in the decision to contract varied from mode to mode. Cost reduction and improved efficiency were cited most frequently for fixed route service, with reducing costs mentioned most often by agencies that contracted all or some service. Cost savings are derived from lower wage rates, and contractors can provide lower rates by hiring new operators at entry-level wage rates, eliminating pensions and other benefits for contract workers, and minimizing the cost of employee health insurance by taking advantage of the large number of employees under their coverage.

Contractors interviewed in the GAO study focused on reducing costs by increasing efficiencies through proprietary technology for routing and scheduling. Advanced technology is often not available to transit agencies outside of a contract, or is expensive for a transit agency to purchase. Another cost saving measure is direct provision of insurance on the vehicles the contractor uses.

\section{Start New and/or Expand Service}

Transit contracting has proven to be successful when implementing new specialized service that does not displace existing unionized workers. A frequently mentioned reason for contracting reported in the literature was to start new service (TRB 2001). When service needs to be established quickly, new 
smaller agencies tend to contract all services, often based on the assumption that a private firm can mobilize faster than a public agency. Contracting provides an agency with the ability to assess and adjust the new service prior to hiring additional in-house labor, and to launch new lines, expand service, or establish an entire agency in the absence of in-house transit resources or expertise. Respondents to the GAO study reported that the decision to contract varied from mode to mode. New commuter rail, light rail, and heavy rail contract out service to avoid high start-up costs (new services, new vehicles, hiring staff, and obtaining facilities). Agencies also contract for service when they lack the capability to perform transit service in-house. Contracting is often used by transit agencies to try out new service with projected low ridership that would not be cost-effective (Iseki, Ford, and Factor 2006).

\section{Allow Additional Flexibility}

Agencies contract service to increase flexibility in how services are provided. Specific circumstances that made contracting out appealing included the ability to test new service to determine sustainability; adjusting the level of service based on increases or decreases in the operating budget; hiring employees for service adjustment; and dealing with human resources when layoffs or employee discipline occurred (Leland and Smirnova 2009). The GAO study reported that improved flexibility is a primary consideration for contracting service. Contractors can operate more efficiently by having their operators split their time between different jobs, and the contractor's workforce is more flexible, with a greater number of part-time positions that reduce costs through decreased wages and benefits. The contractor has the resources of the entire company to serve as a pool for necessary staff, and flexible labor agreements provide the capability to cross-train staff, which enables a dispatcher to drive or a driver to perform dispatching functions when necessary.

\section{Minimize Public Employment and Unionization}

Transit service contracting can be particularly useful for new or smaller agencies. In the case of contracting all service, contracting may support efforts to minimize the number of new public staff to be added, avoid unionization of public employees, or engage in ongoing negotiations with unions (Wachs, Frick, and Taylor 2008). While all transit managers that use contracting interviewed in the GAO study said that Section 13(c) was not a deterrent to contracting, some survey respondents reported that challenges presented by Section 13(c) were a reason for not contracting service.

\section{Political Reasons}

In a 2009 survey of transit managers, some respondents cited political reasons for contracting out services (Leland and Smirnova 2009). Larger agencies with elected boards were much more likely to engage in contracting than agencies located in special purpose governments with appointed boards. Managers found appealing the transfer of risk from elected officials to a private entity, and the insulation provided by the contractor serving as a shield between elected officials and public complaints.

\section{Maintain Service Levels}

Contracting can be used to maintain service levels when faced with budget reductions (GAO-13-782). 


\section{Access to Contractor Resources}

Respondents to the GAO study noted that contracting can provide access to contractors' expertise and resources. Contractors identified the expertise and resources they bring to a transit agency as a benefit in areas such as training and customer call centers, which allow the transit agency to focus on its management strengths. Contracting allows a private company to provide resources that the transit agency does not have. Transit agencies might receive access to expertise for technical issues and labor negotiations, as well as discounted purchasing rates for fuel, vehicle parts, and other equipment due to the large amount purchased by the contractor to cover operations for several transit agencies. 


\section{Reasons Not to Contract Transit Service}

Following are the primary reasons that transit agencies do not contract public transit service, assembled from the literature on the subject. Each of the reasons is discussed in detail.

- Maintain control

- Not cost-effective

- Union contract

- Lack of competition/too few bidders/lack of qualified firms

- Federal Labor Rule - Section 13(c)

- Contract length

- Maintain accountability/service quality

- Type of agency

- Performance measures

- Capital investment/agency funding

- Safety

\section{Maintain Control}

Transit agencies and the literature indicate that a challenge to contracting is that it diminishes an agency's direct control over operations, which, in some cases, may not provide an economic benefit equal to the risks associated with delegating service control to a contractor. Many agencies prefer in-house delivery of transit services because it provides managers with a direct line of authority to adjust services to meet a community's demand or to deal with unforeseen service events.

\section{Not Cost-Effective}

A study published in the Journal of Public Administration Research and Theory (Zullo 2008) found no immediate or long-term economic benefit from contracted bus service, and suggested that administrative costs with respect to contracting appear fixed rather than variable. Cost savings from contracting come primarily from lower driver salaries and benefits, often at the expense of transit service quality. When agencies try to take advantage of the wage gap through contracting, permitting substantially lower wages and benefits for the private-sector driver, they potentially diminish driver and service quality and increase driver turnover, insurance rates, and expenses for training drivers.

Contracting may also not work when agencies fail to identify longer-term contracting costs in search of short-term cost reductions. "Transaction costs" associated with contracting include the cost of soliciting proposals and evaluating bids, negotiating contracts, monitoring contracts, and enforcing penalties for non-compliance. These costs must be fully considered to accurately estimate the savings (or costs) of contracting (Wachs, Frick, and Taylor 2008).

Agencies that do not contract any transit service, or that contract only some aspects of their operations, also do so for reasons that vary by mode. For all modes except commuter rail, the top three reasons not to contract are that the agency desired to maintain control over operations, the agency found no reason 
to change from the transit agency providing service, or the agency found contracting was not costeffective. One of the transit agencies interviewed did not contract for any service, and five contracted only some modes. They cited similar reasons for their decisions not to contract service. The agencies never considered contracting due in part to difficulty in finding a contractor willing to implement a costly drug and alcohol program that met FTA standards. Another reason cited was that contracting out maintenance services would have been more expensive than directly operating it themselves, according to a comparative analysis performed by the transit agency of the cost to contract versus the cost of in-house maintenance. One transit agency contracted service in the past and decided to bring the service back in-house after an analysis determined that the agency's costs to operate the service were lower than the privately contracted options (GAO-13-782).

Public agencies' policy decisions are affected not only by economic factors, but also by political, fiscal, institutional, and transit-system factors. An agency whose decision makers prefer a small government directly providing less public service may contract service even when it is uncertain about the economic effects. Different sizes of agencies have different patterns of contracting; among agencies that contract, small agencies tend to contract out all service, while large agencies are likely to contract out only a portion of their service (Iseki 2010).

Officials at two transit agencies said the contracting process is complex, long, and arduous. One agency indicated they start the contract solicitation process approximately one year prior to the expiration of the existing contract. The process includes writing the scope of work, updating requirements (which includes obtaining input from various departments within the agency), issuing the request for proposal, evaluating the responses, negotiating with the selected contractor, and monitoring any start-up activities. The transaction costs incurred could offset or even exceed cost savings from contracting transit service operation and management functions. Some studies suggest that the costs of monitoring the contractor's performance may, in some cases, outweigh the benefits. The GAO study found that transit agencies may need to keep in-house staff to evaluate and monitor contracts, reducing efficiency gains and cost-related savings.

\section{Union Contract}

Contracting may not work when well-utilized, regular, in-house bus service is transferred to the private sector, particularly if that service is already efficiently delivered by public-sector employees. Labor groups will likely oppose such conversion because these services are traditionally their members' core employment and livelihood. In this scenario, it may be more advantageous for an agency to negotiate changes to work rules to maximize vehicle and driver utilization and reduce costs (Wachs, Frick, and Taylor 2008). Larger, older agencies are more likely to contract out only a portion of service because they have long histories of public provision of services by unionized public employees, and political battles would likely ensue if the system moved toward contracting with private companies.

Even when contracting is likely to reduce costs and improve cost-efficiency, an agency may choose not to contract because concessions granted to unions in the negotiation process could make overall service 
much more expensive. Furthermore, elected officials on the board could favor in-house service for perceived political support.

Transit agencies that are unionized must consider how organized labor would react to a contracting decision (Iseki, Ford, and Factor 2006). While a union may concede to contracting out new services, it tends to show much stronger opposition to contracting out existing services, which threatens union members' current jobs. However, according to one study, while most agencies with some in-house service are sensitive to union resistance to contracting, they may also face financial distress and be forced to find ways to increase cost-efficiency. Maintaining a good relationship and open communication with the union enables both parties to work together to increase cost-efficiency of in-house service, while avoiding significant job losses due to contracting. Even when transit managers are aware of other strategies for increasing cost-efficiency, they need cooperation and concessions from the union to implement them (GAO-13-782).

\section{Lack of Competition/Too Few Bidders/Lack of Qualified Firms}

Contracting may not work when there is an inadequate number of potential qualified private contractors to bid on service contracts, particularly if part of the purpose of contracting is to generate competition among bidders. Unequal competition in the bidding process with a few dominant vendors can erode competition in the bidding process that would improve the efficiency and effectiveness of contracting (Wachs, Frick, and Taylor 2008).

\section{Federal Labor Rule - Section 13(c)}

Some GAO survey respondents reported the challenges presented by Section 13(c) as a reason for not contracting out service.

\section{Contract Length}

The long term length of existing contracts, 5.5 years on average, and the unequal competition in the bidding process (a few dominant vendors), likely erode the competition in the bidding process that would improve the efficiency and effectiveness of contracting out with a private vendor for services (Leland and Smirnova 2009).

\section{Maintain Accountability/Service Quality}

In the Transportation Research Board's (TRB) Special Report 258, Contracting for Bus and DemandResponsive Transit Services, the most common survey response for not contracting was an agency's desire to maintain accountability and service quality. The capacity to manage the contract can be impacted by questionable ethics used by vendors in the bidding process. Highly aggressive and questionable tactics used to entice employees from one contractor to another, interfering with what should be an independent decision-making process, submitting intentionally low bids, and deferred maintenance can negatively influence the contract management process (Leland and Smirnova 2009). Inadequate oversight could actually reduce efficiency in contracted service (Iseki 2010). 


\section{Type of Agency}

The type of agency may moderate the effect of contracting on cost-efficiency. Different agencies are subject to different institutional and political conditions that may influence how contracting affects costefficiency (Iseki 2010).

\section{Performance Measures}

Contracts that fail to relate performance measures to a contractor's profits present a challenge to contracting. Historically, agencies have gone above and beyond to ensure high-quality service. Because contractors are profit driven, they may not be motivated to provide the same level and quality of service as the transit agencies (Iseki 2010).

\section{Capital Investment/Agency Funding}

Three of the six contractors interviewed in the GAO survey said that the capital investment required for a contract might prevent them from bidding. One contractor identified transit agency funding as the biggest barrier to contracting, when agencies are driven into a contracting arrangement based on price rather than value because of funding constraints.

\section{Safety}

A major concern about contracting expressed by national and local union officials interviewed in the GAO study was that contracting might lead to a decreased level of safety, poor service quality, and hidden costs, when contracted employees receive less training than transit agency employees. Nonetheless, officials at all of the nine agencies that use contractors reported that they oversee contractor performance through various activities, including inspecting contractor facilities or vehicles, and none of the officials interviewed raised concerns about safety. One transit agency said that officials inspect the contractors' buses on a daily basis to determine their condition and whether preventive maintenance or repairs have been performed. The agency also reviews performance data related to customer complaints, on-time performance, accidents, and maintenance, which it compiles in a monthly report. 


\section{Operating Contracts Executed in Identified Areas}

Transit agencies are required to report a variety of service metrics along with operating and financial information to the NTD. Within the NTD, transit service is designated by type of service, which includes service directly operated by the agency and service purchased by the agency from a private provider or another transit agency. Since NTD reporting requirements apply specifically to transit agencies regardless of organization type, rather than to private service providers or contractors, transit agencies are responsible for reporting information and metrics for both DO and PT service. Agencies that purchase services are required not only to describe the contractual relationship between the reporting agency and the service provider, but also to identify the company or transit agency that provides the service to avoid duplicative reporting (NTD Form B-30). In addition, reporting agencies are required to detail the monetary nature of the contractual relationship using the following descriptors:

- Negotiated rate per unit of service delivered (e.g., cost per revenue hour)

- Cash reimbursement of some of seller's operating deficit

- Cash reimbursement of all of seller's deficit

- Cash reimbursement to seller of reduced fare programs

- Vehicles given, sold, loaned, or leased for below market value to the seller

- Maintenance facility leased to seller

- Cash payment to seller for specific mass transportation services

- Other

Using the 2011 NTD (most recent version available), researchers examined the nature of contracting for rail and fixed route bus service reported by all transit agencies operating in California (CA), Georgia (GA), Louisiana (LA), and New York (NY). Researchers also reviewed transit agencies operating in Florida (FL) to identify the characteristics of contracting practices currently in place statewide.

An agency in each of the states included in the review operated at least a single rail system. Agencies in New York directly operated their rail service, as did the single agency operating rail service in Georgia. The single rail agency operating in Louisiana purchased all rail service. In California, 41.7 percent of agencies purchased all or some rail service from four service providers, using a combination of a negotiated rate per unit of service and cash reimbursement of the seller's deficit. In Florida, one of four agencies (25.0\%) purchased rail service from a single provider, based on a negotiated rate per unit of service.

California, Louisiana, and Florida agencies provided vehicles to their contractors. California agencies assisted two contractors with the costs of fuel and other supplies.

Under Louisiana's delegated management contract, the agency defined the monetary nature of its contractual relationship as other. 
Overall, 57.1 percent of the agencies that purchased all or some rail service compensated the contractor based on a negotiated rate per unit of service delivered.

Details of the contractual arrangements for rail services are presented in Table 1.

Table 1 - Monetary Nature of Contractual Relationship - Rail

\begin{tabular}{|l|c|c|c|c|c|}
\hline Rail Service & CA & GA & LA & NY & FL \\
\hline Agencies & 12 & 1 & 1 & 5 & 4 \\
Purchased all or some service & 5 & 0 & 1 & 0 & 1 \\
\% purchased all or some service & $41.7 \%$ & $0.0 \%$ & $100.0 \%$ & $0.0 \%$ & $25.0 \%$ \\
Directly operated all service & 7 & 1 & 0 & 5 & 3 \\
\% directly operated all service & $58.3 \%$ & $100.0 \%$ & $0.0 \%$ & $100.0 \%$ & $75.0 \%$ \\
Number of service providers & 4 & 0 & 1 & 0 & 1 \\
Negotiated rate per unit of service delivered & 3 & 0 & 0 & 0 & 1 \\
Cash reimbursement of all of seller's deficit & 2 & 0 & 0 & 0 & 0 \\
Fixed fee + variable fee & 0 & 0 & 1 & 0 & 0 \\
Agency provided vehicles & 5 & 0 & 1 & 0 & 1 \\
Paid or assisted with costs of fuel/other supplies & 2 & 0 & 0 & 0 & 0 \\
\hline
\end{tabular}

Agencies within each of the states included in the review purchased all or some fixed route bus service. In California, 73.8 percent of the agencies purchased all bus service from 29 service providers, using primarily a negotiated rate per unit of service.

Agencies in each state provided vehicles to their contractors. Agencies in California, Georgia, and New York also assisted some of their contractors with the costs of fuel and other supplies.

Agencies in Georgia and Florida purchased service from a sister agency. California, Georgia, and Florida agencies negotiated different monetary arrangements with service providers.

Under a delegated management contract, a Louisiana agency compensated the contractor with a fixed fee payment in addition to a variable fee payment based on a negotiated rate per platform hour.

Overall, 77.8 percent of the agencies that purchased all or some fixed route bus service compensated the contractor based on a negotiated rate per unit of service delivered.

Details of the contractual arrangements for fixed route bus services are presented in the following table (Table 2). 
Table 2 - Monetary Nature of Contractual Relationship - Bus

\begin{tabular}{|l|c|c|c|c|c|}
\hline Fixed Route Bus Service & CA & GA & LA & NY & FL \\
\hline Agencies & 80 & 15 & 9 & 36 & 30 \\
Purchased all or some service & 59 & 5 & 3 & 11 & 12 \\
\% purchased all or some service & $73.8 \%$ & $33.3 \%$ & $33.3 \%$ & $30.6 \%$ & $40.0 \%$ \\
Directly operated all service & 21 & 10 & 6 & 25 & 18 \\
\% directly operated all service & $26.3 \%$ & $66.7 \%$ & $66.7 \%$ & $69.4 \%$ & $60.0 \%$ \\
Purchased service from sister agency & 0 & 3 & 0 & 0 & 3 \\
Contracted with multiple providers & 14 & 1 & 0 & 2 & 3 \\
Different monetary arrangements with providers & 9 & 1 & 0 & 0 & 1 \\
Number of service providers & 29 & 4 & 2 & 17 & 14 \\
Negotiated rate per unit of service delivered & 47 & 5 & 1 & 9 & 8 \\
\% negotiated rate per unit of service delivered & $79.7 \%$ & $100.0 \%$ & $33.3 \%$ & $81.8 \%$ & $66.7 \%$ \\
Cash reimbursement of all of seller's deficit & 3 & 1 & 0 & 0 & 0 \\
Cash reimbursement of some of seller's deficit & 6 & 0 & 1 & 0 & 3 \\
\hline Fixed fee + variable fee & 0 & 0 & 1 & 0 & 0 \\
Agency provided vehicles & 41 & 4 & 1 & 8 & 8 \\
Agency leased maintenance facility & 4 & 0 & 1 & 0 & 1 \\
Paid or assisted with costs of fuel/other supplies & 11 & 1 & 0 & 1 & 0 \\
\hline
\end{tabular}




\section{Review of Five Transit Agency Contracts}

Contracting methods were explored through an examination of select transit agency contracts with private service providers. Researchers reviewed the following transit contracts to identify the nature of the contractual relationships.

1. Transit Services Agreement awarded on January 1, 2007, by the City of Petaluma, California, to MV Transportation, Inc. (City of Petaluma)

2. Management Agreement awarded on October 3, 2008, and amended to transition to a Delegated Management Contract on September 1, 2009, by the New Orleans Regional Transit Authority, Louisiana, to Veolia Transportation Services, Inc. (New Orleans)

3. Management and Operations of Public Transportation Services Agreement awarded on September 15, 2011, by the Parish of Jefferson, Louisiana, to Veolia Transportation Services, Inc. (Jefferson Parish)

4. Delegated Management Agreement awarded on January 1, 2012, by Nassau County, New York, to Veolia Transportation Services, Inc. (Nassau County)

5. Transit Management Agreement awarded on April 1, 2012, by Escambia County, Florida, to First Transit, Inc. (Escambia County)

Despite the nomenclature used to identify each of the contracts, the operating practices outlined in the contracts, as illustrated below, are quite similar. Details are presented in Appendix A.

\section{Contract Similarities}

In each case, the contractor is defined as an independent contractor. All agencies supply revenue vehicles to the contractor for the contractor's use, after a joint inspection, and provide facilities to the contractor for the contractor's use.

All contractors are responsible for the condition of equipment and maintenance of vehicles. Contractors are required to provide drivers, supervisors, and personnel for all classifications. Escambia County includes an employment preference for local labor.

All contractors are responsible for labor negotiations. Escambia County requires that the contractor notify the County of any changes in the union employee wage rate.

All contractors are responsible for fare collection and reconciliation. The City of Petaluma requires the contractor to submit reports to the City each month that include daily fare collection. Nassau County also provides the contractor with specific reporting requirements.

All contractors are required to provide safety and security. The City of Petaluma issues specific requirements to the contractor and requires the contractor to develop and distribute an IIIness \& Injury Prevention Plan. Jefferson Parish also issues specific requirements to the contractor, and requires the contractor to submit a plan to increase overall traffic at a transit terminal to improve transit safety and security. 
All contractors are responsible for regular monthly reporting. The City of Petaluma issues specific requirements for daily, weekly, and monthly reports. New Orleans requires the contractor to include system expenditures, financial records, and operating records in monthly reports. Jefferson Parish issues specific requirements for monthly reports. Nassau County requires the contractor to submit Performance Measures and a Performance Scorecard. Escambia County requires annual reporting requirements.

All contractors are responsible for FTA/NTD reporting, ensuring compliance with Drug-Free Workplace requirements, the provision of all software and hardware, providing customer information service, and managing customer complaints. The City of Petaluma requires that the contractor respond to complaints, maintain a log, and report to the City as specified in the agreement. Escambia County requires the contractor to maintain a Complaint Tracking Database.

All contractors, with the exception of the City of Petaluma, are required to provide marketing and advertising.

\section{Differences in Contracts}

The terms of the contracts range from three years for the City of Petaluma and Jefferson Parish to five years for New Orleans, Nassau County, and Escambia County.

There is variation in contract renewals/extensions, as detailed below:

- Jefferson Parish - no reference to renewal or extension

- City of Petaluma - two-year option upon mutual consent of the parties, subject to the city council's approval

- Escambia County - two-year extension upon mutual consent of the parties

- New Orleans - option to renew automatically upon (1) contractor meeting performance criteria, and (2) contractor's significant investment in the transit system, or by mutual consent

- Nassau County - five-year renewal at County's discretion

There is also variation in the following descriptions of the contract services:

- City of Petaluma - fixed route operations, administrative, and maintenance-related functions

- New Orleans - manage all transit system functional responsibilities, operations, and maintenance

- Jefferson Parish - manage and operate

- Nassau County - manage and operate

- Escambia County - manage, operate, and maintain

New Orleans designates the contractor as the party responsible for non-revenue vehicles, and Nassau County restricts the cost to maintain non-revenue vehicles during the first year of the contract to $\$ 20,000$. The other agencies do not address non-revenue vehicles.

Adjustment in the unit cost varied across the contracts, as illustrated below: 
- City of Petaluma - renegotiate if revenue hours $<90 \%$ or $>110 \%$; restricts an annual increase to $3 \%$ based on the Consumer Price Index (CPI) in the Management Services Agreement (MSA)

- New Orleans - agency and contractor negotiate fixed fee (adjusted annually) and variable fee (based on platform hour rate), pursuant to annual plan and budget

- Jefferson Parish - renegotiate rate if revenue hours increase or decrease by more than $10 \%$

- Nassau County - agency and contractor negotiate fixed fee (adjusted annually) and variable fee (based on platform hour rate), pursuant to annual plan and budget

- Escambia County - contractor may recommend rate adjustment to cover increases or decreases in cost structure; contractor may submit proposal for increase in the case of extraordinary events

The City of Petaluma and Jefferson Parish provide the service plan, and reserve the right to adjust the service plan to meet the agency's needs. New Orleans, Nassau County, and Escambia County require the contractor to provide the service plan. New Orleans' service plan is subject to agency approval. Nassau County's service plan is subject to Transit Committee approval. Escambia County reserves the right to adjust the service plan in writing.

The City of Petaluma and Jefferson Parish provide the fare policy and hours of service. The City of Petaluma reserves the right to adjust the fare policy and hours of service at the City's sole discretion. Jefferson Parish reserves the right to adjust the fare policy and hours of service to meet the agency's needs. New Orleans, Nassau County, and Escambia County require the contractor to provide the fare policy and hours of service. New Orleans' fare policy and service hours are subject to agency approval. Nassau County's fare policy and service hours are subject to Transit Committee approval. Escambia County reserves the right to adjust the fare policy and service hours in writing.

Responsibility for contract compliance rests with the City of Petaluma project manager, New Orleans Authority Board, Jefferson Parish Department of Transit Administration, Nassau County, and the Escambia County administrator or designated representative.

The City of Petaluma, New Orleans, and Jefferson Parish provide fuel to the contractor. The contractor is required to provide fuel in Nassau County and Escambia County.

Personnel mandated within the contracts varied, as illustrated below:

- City of Petaluma - project manager, mechanic, half-time road supervisor, and general manager

- New Orleans - chief executive officer, chief financial officer, chief operating officer, chief maintenance officer, marketing director, human resources director, director scheduling/planning, director of procurement, executive consulting personnel, and technical assistance

- Jefferson Parish - project manager, maintenance manager, agency issues specific requirements

- Nassau County - chief executive officer and chief operating officer

- Escambia County - general manager, subject to County approval 
Fare box recovery within the contracts varied, as follows:

- City of Petaluma - contractor must satisfy Transportation Development Act requirement that $15 \%$ of monthly operating cost be obtained from the fare box revenue for fixed route; any shortfall in the $15 \%$ must be paid by the contractor at the end of the year

- New Orleans - no liability for revenue shortages

- Jefferson Parish - agency requires $100 \%$ collection from the fare box

- Nassau County - beginning with the second budget year, if fare box revenue falls short of annual or exceeds projected revenue, contractor is responsible for or receives surplus or shortfall up to $5 \%$ of annual projected fare box revenue; contractor may renegotiate financial terms if shortfall is $>10 \%$ for two quarters

- Escambia County - contractor is responsible for fare box recovery

Escambia County is responsible for payment of all operating expenses, but the contractor must retain necessary working capital equal to fund at least 60 days of operating expenses; Escambia County will pay on a cash reimbursement basis.

The City of Petaluma contractor may earn an incentive of up to $\$ 500$ per quarter for increased ridership of $>10 \%$ over the average of the past two quarters.

\section{Liquidated Damages}

No liquidated damages were identified for New Orleans or Escambia County. Liquidated damages detailed for the City of Petaluma, Jefferson Parish, and Nassau County are provided below in Table 3.

Table 3 - Liquidated Damages

\begin{tabular}{|c|c|c|}
\hline City of Petaluma & Jefferson Parish & Nassau County \\
\hline $\begin{array}{l}\text { Contractor charged each time } \\
\text { default occurs: } \\
\text { - \$100 per non-trainee driver’s } \\
\text { failure to wear an approved } \\
\text { uniform while on duty } \\
\text { - \$50 per trip for driver's failure to } \\
\text { announce major intersections, } \\
\text { transfer opportunities, and } \\
\text { major activities as required by } \\
\text { the Americans with Disabilities } \\
\text { Act (ADA) } \\
\text { - \$50 per missed trip that was in } \\
\text { contractor's control } \\
\text { - Maximum liquidated damages in } \\
\text { any month must not exceed } \\
\$ 1,000\end{array}$ & $\begin{array}{l}\text { - \$100 per day will begin to accrue } \\
\text { and payable on the } 16^{\text {th }} \text { day of } \\
\text { each month until the manager } \\
\text { receives monthly reports } \\
\text { - \$100 per day per vehicle } \\
\text { assessed against monthly invoice } \\
\text { for vehicles reported as dirty for } \\
\text { two consecutive days } \\
\text { - \$100 per day for inoperable air } \\
\text { conditioning and heating longer } \\
\text { than the same day of breakdown } \\
\text { - \$100 per day for operating } \\
\text { vehicles that have failed the } \\
\text { safety inspection } \\
\text { - \$5,000 for each event of false or } \\
\text { misleading information given to } \\
\text { the agency for any instance as } \\
\text { delineated in the agreement }\end{array}$ & $\begin{array}{l}\text { - Contractor must pay } \$ 5,000 \text { for } 5 \\
\text { percentage points worse than } \\
\text { benchmark for on-time } \\
\text { performance } \\
\text { - Contractor must pay } \$ 2,000 \text { for } 5 \\
\text { percentage points worse than } \\
\text { benchmark for percentage of } \\
\text { missed pullouts } \\
\text { - Contractor must pay } \$ 5,000 \text { for } \\
10 \% \text { worse than the benchmark } \\
\text { for accidents per } 100,000 \text { miles }\end{array}$ \\
\hline
\end{tabular}




\section{Performance Measures}

Performance measures contained in each of the contracts are presented in Table 4 . The City of Petaluma, Nassau County, and New Orleans incorporated performance metrics common within the transit industry-on-time performance, accident frequency, and ridership growth. Escambia County required the contractor to certify quarterly on-time performance of at least 90 percent, and Jefferson Parish required the contractor to submit a plan to increase ridership at least 10 percent within the first year of the contract.

Table 4 - Transit Agency Performance Measures

\begin{tabular}{|c|c|c|c|c|}
\hline $\begin{array}{c}\text { City of Petaluma Transit } \\
\text { Services Agreement }\end{array}$ & $\begin{array}{c}\text { New Orleans RTA } \\
\text { Delegated Management } \\
\text { Agreement }\end{array}$ & $\begin{array}{c}\text { Jefferson Parish } \\
\text { Management \& } \\
\text { Operations of Public } \\
\text { Transportation } \\
\text { Services Agreement }\end{array}$ & $\begin{array}{l}\text { Nassau County } \\
\text { Delegated } \\
\text { Management } \\
\text { Agreement }\end{array}$ & $\begin{array}{c}\text { Escambia County } \\
\text { Transit } \\
\text { Management } \\
\text { Agreement }\end{array}$ \\
\hline $\begin{array}{l}\text { Reported monthly by } \\
\text { contractor: } \\
\text { - Miles between road } \\
\text { calls } \\
\text { - Miles between } \\
\text { maintenance road calls } \\
\text { - \# and \% of missed/late } \\
\text { pull-outs } \\
\text { - \# and \% of missed/late } \\
\text { trips } \\
\text { - \# and \% of on-time } \\
\text { performance } \\
\text { - \# of complaints/1,000 } \\
\text { passengers } \\
\text { - Total accidents/ } \\
100,000 \text { miles } \\
\text { - Collision accidents/ } \\
100,000 \text { miles } \\
\text { - Ridership by day, } \\
\text { mode, route, and fare } \\
\text { type } \\
\text { - Total preventable } \\
\text { accidents/100,000 } \\
\text { miles } \\
\text { - Passenger accidents } \\
\text { per } 100,000 \text { miles } \\
\text { - Pass sales activity at } \\
\text { dispatch office } \\
\text { - Wheelchair boardings } \\
\text { - Drug \& alcohol tests } \\
\text { - Driver/dispatcher } \\
\text { - Drining activities } \\
\text { currently provided }\end{array}$ & $\begin{array}{l}\text { - Invest in in-house } \\
\text { technical resources for } \\
\text { development/ } \\
\text { financing of creation/ } \\
\text { expansion of rail } \\
\text { systems } \\
\text { - Strive to improve } \\
\text { operating performance } \\
\text { for safety (current } \\
\text { preventable traffic } \\
\text { accident frequency: } \\
\text { bus } 2.0, \text { streetcar } 5.06 \text { ) } \\
\text { - On-time service } \\
\text { (current: bus } 88 \%, \\
\text { streetcar } 85 \% \text { ) } \\
\text { - Passenger growth } \\
\text { (current: bus } 19 \text { per } \\
\text { hour, streetcar } 37 \text { per } \\
\text { hour) } \\
\text { - Invest in agency's } \\
\text { infrastructure } \\
\text { - Provide services to } \\
\text { seek public funding at } \\
\text { local, state, and } \\
\text { federal levels } \\
\text { - Provide a national } \\
\text { Emergency Response } \\
\text { Team in the event of a } \\
\text { natural disaster } \\
\text { - Seek to reduce } \$ 151.17 \\
\text { operating cost per } \\
\text { hour by } 25 \% \\
\text { throughout contract } \\
\text { term (adjusted for } \\
\text { inflation) }\end{array}$ & $\begin{array}{l}\text { - Contractor must } \\
\text { submit } \\
\text { implementation } \\
\text { plan to increase } \\
\text { ridership at least } \\
10 \% \text { within first } \\
\text { year of agreement }\end{array}$ & $\begin{array}{l}\text { Performance } \\
\text { Scorecard: } \\
\text { - Revenue hours } \\
\text { - Service miles } \\
\text { operated } \\
\text { - Cost per mile } \\
\text { - Revenue per mile } \\
\text { - Cost recovery } \\
\text { - \% of miles @ 100\% } \\
\text { recovery } \\
\text { - Calls answered } \\
\text { ratio } \\
\text { - Pass-ups } \\
\text { - On-time \% } \\
\text { - Customer } \\
\text { satisfaction score } \\
\text { - Net promoter } \\
\text { score } \\
\text { - Missed trips } \\
\text { - Mechanical } \\
\text { breakdowns per } \\
\text { week } \\
\text { - Accidents per } \\
\text { 100,000 miles } \\
\text { - Bus cleanliness* } \\
\text { - Stop cleanliness* } \\
\text { - On-time } \\
\text { perception* } \\
\text { * These measures } \\
\text { were listed as } \\
\text { tentative and } \\
\text { subject to } \\
\text { modification or } \\
\text { replacement }\end{array}$ & $\begin{array}{l}\text { - Contractor must } \\
\text { certify quarterly } \\
\text { on-time } \\
\text { performance of } \\
\text { at least 90\% } \\
\text { - Implement Rider } \\
\text { Technology } \\
\text { within three } \\
\text { months } \\
\text { - Establish and } \\
\text { maintain a } \\
\text { Geographic } \\
\text { Information } \\
\text { System (GIS) } \\
\text { layer for all } \\
\text { routes, stops, } \\
\text { benches, and } \\
\text { shelters within } \\
\text { six months } \\
\text { - Implement } \\
\text { Escambia County } \\
\text { Transit } \\
\text { Development } \\
\text { Plan (TDP) within } \\
\text { six months } \\
\text { - Contractor will } \\
\text { periodically } \\
\text { propose } \\
\text { alternatives for } \\
\text { poor performing } \\
\text { routes, subject to } \\
\text { County approval }\end{array}$ \\
\hline
\end{tabular}


The City of Petaluma incorporated a variety of operations and maintenance metrics, including miles between road calls, missed and late trips, pass sales, wheelchair boardings, drug and alcohol testing, and driver-related training and evaluations. Both the City of Petaluma and Nassau County measured customer satisfaction.

Nassau County identified various performance metrics related to cost that included cost per mile, revenue per mile, and percent of miles at 100 percent recovery, and New Orleans required the contractor to seek to reduce the $\$ 151.17$ operating cost per hour by 25 percent throughout the contract term.

Escambia County identified two technology-related performance measures that required the contractor to implement rider technology within three months, and to establish and maintain a GIS layer for all routes, stops, benches, and shelters within six months.

New Orleans appears to be the only agency that required the contractor to invest in in-house technical resources for development or financing of new or expanded rail service, invest in the agency's infrastructure, provide services to seek public funding at local, state, and federal levels, and provide a national Emergency Response Team in the event of a natural disaster.

\section{Payment Schedule}

At a minimum, all contractors were compensated through a fixed fee arrangement paid in monthly installments, as illustrated in Table 5. Escambia County was the only agency that reimbursed the contractor for all operating expenses incurred, in addition to the payment of the fixed fee for management services.

The City of Petaluma, New Orleans, and Nassau County paid a variable fee based on a negotiated rate per platform hour, in addition to the monthly fixed fee.

Table 5 - Transit Contract Payment Schedules

\begin{tabular}{|c|c|c|c|c|c|}
\hline $\begin{array}{l}\text { Method } \\
\text { of } \\
\text { Payment }\end{array}$ & $\begin{array}{c}\text { City of } \\
\text { Petaluma } \\
\text { Transit Services } \\
\text { Agreement }\end{array}$ & $\begin{array}{l}\text { New Orleans } \\
\text { RTA Delegated } \\
\text { Management } \\
\text { Agreement }\end{array}$ & $\begin{array}{c}\text { Jefferson Parish } \\
\text { Management \& } \\
\text { Operations of Public } \\
\text { Transportation Services } \\
\text { Agreement }\end{array}$ & $\begin{array}{l}\text { Nassau County } \\
\text { Delegated } \\
\text { Management } \\
\text { Agreement }\end{array}$ & $\begin{array}{c}\text { Escambia County } \\
\text { Transit } \\
\text { Management } \\
\text { Agreement }\end{array}$ \\
\hline $\begin{array}{l}\text { Fixed fee } \\
\text { (monthly) }\end{array}$ & $\$ 23,801$ & $\$ 1,390,732 *$ & $\$ 823,888$ & $\$ 2,319,664$ & $\$ 32,750-\$ 34,754$ \\
\hline $\begin{array}{l}\text { Variable } \\
\text { fee }\end{array}$ & $\begin{array}{c}\$ 22.82 \text { per } \\
\text { gate-to-gate } \\
\text { hour }\end{array}$ & $\begin{array}{l}\$ 76.86 \text { per } \\
\text { fixed route } \\
\text { platform hour }\end{array}$ & & $\begin{array}{l}\$ 87.12 \text { per } \\
\text { fixed route } \\
\text { platform hour }\end{array}$ & \\
\hline $\begin{array}{l}\text { Operating } \\
\text { expenses }\end{array}$ & $\begin{array}{l}\text { Contractor pays } \\
\text { all operating } \\
\text { expenses }\end{array}$ & $\begin{array}{l}\text { Contractor pays } \\
\text { all operating } \\
\text { expenses }\end{array}$ & $\begin{array}{l}\text { Contractor pays all } \\
\text { operating expenses }\end{array}$ & $\begin{array}{l}\text { Contractor pays } \\
\text { all operating } \\
\text { expenses }\end{array}$ & $\begin{array}{l}\text { County reimburses } \\
\text { all authorized } \\
\text { operating } \\
\text { expenses }\end{array}$ \\
\hline
\end{tabular}

*Includes fixed route, streetcar rail, and paratransit service. 


\section{Lessons Learned from Transit Contracting Experience}

Researchers turned to individual transit agencies to explore lessons learned from their contracting experience. Understanding problems and successes encountered by transit agencies currently engaged in contracting provides valuable insight, not only for agencies that are considering contracting some or all service for the first time, but also for agencies interested in improving their existing contractual relationships with service providers. While most lessons learned are derived from anecdotal accounts, rather than from extensive study of an agency's operating practices, they prove to be valuable, at a minimum, by simply identifying problems and issues encountered in the contracting process.

\section{Request for Proposal}

\section{Tailor Request for Proposal to Meet Service Needs}

In May 2011, a transit agency awarded a transit service contract to a new contractor, which was the low bidder and $\$ 50$ million less than the current contractor, which had been the service provider for the past 20 years. Following a protest on the part of the current provider, the agency rescinded the contract with the low bidder. The low bidder sued the agency, and FTA intervened due to concerns about the use of federal funds. Subsequently, the agency and the low bidder reached an agreement that called for the contract bidding process to begin again, but with the bus system split in two. The agency awarded two new bus operator contracts in February 2013. Neither the original contractor nor the low bidder in the first bid process was successful in the competition.

\section{Contract Award}

\section{Conduct Cost Analysis Prior to Award to Ensure Fiscally Responsible Bid}

A contractor had been losing money under the current three-year contract that would have expired in June 2014. In January 2013, the agency addressed the contractor's losses by covering half of the contractor's deficit with an $\$ 18,000$ payment, with the contractor assuming internally the other 50 percent deficit. The agency informed the contractor that there should be no more fiscal issues regarding the agreement for the remainder of the contract term. In February 2013, the union threatened to strike if contract negotiations for a new union contract fell through. The contractor's bus drivers were paid an average of $\$ 11.43$ an hour, while the state average was $\$ 18.73$ an hour; the strike was averted after "negotiations ended amicably." The agency decided to issue a request for proposal (RFP) beginning in January 2014 instead of using the option years in the contract with the contractor, because the transit director believed the current contract "may not be profitable." The agency used "emergency procurement rules," and interested companies had 15 days to submit proposals. Three companies submitted proposals. In June 2013, a year before expiration of the existing contract, the agency and the contractor mutually ended their contract, and the agency awarded a one-year transit operations and maintenance agreement that ends in June 2014 to a new contractor. At the end of the new one-year contract, the agency will request bids for a five-year contract. Bid evaluation criteria included experience of senior staff; the ability to provide high-quality service at a competitive price; and retention of existing employees at the same or better wages. The board said the new contract had been "significantly 
changed" to make it more "fiscally sustainable" and either side could increase or decrease the price by 10 percent without changing the contract. The contract left no room for "we're underpriced because of economic circumstances." If it came to that, then service levels would be adjusted accordingly.

\section{Conduct Cost Analysis Prior to Extension/Renewal to Ensure Effectiveness}

In August 2007, prior to the expiration of a current contract term, a transit agency agreed to increase the current contractor's management fees by a collective $\$ 7$ million on its two contracts without a competitive proposal. FTA requires the completion of a detailed cost analysis for renewal or extension of a bus contract, which the agency did; however, the results of the analysis (which included a comparison with three properties, all operated by the current contractor) were not available when the city council approved the contract.

\section{Contract Awarded for Factors Other Than Cost}

A transit agency committee evaluated four companies bidding to provide bus service, using the following criteria: experience, thoroughness of the proposed management plan and other plans, and solutions for maximizing service and cost-efficiency. Staff recommended the five-year contract go to a new contractor rather than to the current firm (low bidder). In March 2013, the board awarded the contract to the new contractor, which will take over bus operations in July under a contract that will cost $\$ 7.5$ million more over seven years than the current contractor's bid, mainly due to employee costs. A staff report said that the current contractor's long-term fiscal projections seemed artificially low, given anticipated future expenses. The new contractor will administer an employee bonus fund to provide performance-based rewards and incentives, and an employee wellness fund to develop health and fitness programs.

\section{Conduct Cost Analysis Prior to Award for Long-Term Budgetary Sufficiency}

When a transit agency partnered with a contractor in July 2010, a board member stated that the relationship would open new funding opportunities and improve efficiency. About three years into the five-year delegated management contract, the authority board voted to end the partnership and gave the contractor 45 days to transfer management back to the authority. The board chairman concluded that the private operator was becoming too expensive ( $5 \%$ of operating budget). The return to selfmanagement included a significant shift of human resources since drivers, mechanics, and other workers had become employees of the contractor after the agreement. The labor agreement had to be revised, and some details regarding the transfer of pension plans had to be resolved.

\section{Ensure Contract Provisions Are Enforceable}

When a current contractor first bid on an agency bus contract, it allegedly objected to all fines the agency planned to assess for performance. Transit agency officials told the contractor that unless it withdrew the objections, the contractor could not bid on the contract. Company officials withdrew their objections. A new five-year management and operations contract was awarded to the current contractor in June 2010, with a start date in July 2010. 


\section{Ensure Contract Provisions Are Enforceable and Contract Oversight Delineated}

A transit agency had established standards that covered such things as regulations for fuel in vehicles, bus cleanliness, unauthorized stops, and on-time performance. From July 2008 through August 2010, the agency levied more than $\$ 160,000$ in assessments covering nearly 300 violations. There were allegations that the contractor attempted to resolve the issue of the fines in direct meetings with the city council rather than with transit staff, as delineated in the contract. A 2010 audit by the commission that oversaw transit funding in the service area found that bus service performance "exhibited mostly negative trends in all areas" related to efficiency and productivity. The transit agency hired a consultant to compare the dynamics of bus operations with other contracts; the agency apparently employed fines more aggressively than all but one of the four agencies reviewed. An agency study resulted in six recommendations, all of which were enacted. The recommendations included focusing on performance violations that most affect reliable service (modified assessment parameters), having team-building sessions among city officials and contractor officials, and having assessments for violations approved by the public works director and assistant public works director for at least a year (restored responsibility to transit).

\section{Contractor Performance}

\section{Monitor Contractor's Performance and Conform to Procurement Rules}

A contractor allegedly made late payments to vendors, including employee insurance and utility companies, failed to report accidents on time, and conducted improper drug testing procedures. The transit agency terminated the transit service contract in February 2013 due to performance. The terminated contractor protested the new bid award for violation of procurement code and state open meeting laws. The district court ordered a stay in the litigation so the transit agency and contractor could enter mediation mandated by their contract. Attempts to restore an agency-run system failed to pass, and the agency awarded a contract to the new successful bidder in July 2013.

\section{Monitor Contractor's Performance for Improved Customer Service and Compliance with Service Standards}

In spring 2011, a city council, acting in its capacity as the mass transit board, directed staff to research various options for contracting services. The council partnered with Texas Transportation Institute (TTI) to analyze options and make a recommendation for the scope of services to be included in the RFP. The three options included transit management for fixed route, transit management for fixed route and paratransit, and a transit service contract for paratransit. Proposals were evaluated by a team comprising staff from the City Manager's office, Human Resources, Comptroller, General Services, Aviation, TTI, the agency, and the Office of Management and Budget. The process was observed by a City representative, who was a member of the Citizen's Advisory Committee and Human Resources staff. The City awarded a transit management contract for fixed route service, and will continue to maintain oversight over fixed route services to ensure that customer service improves, and ongoing compliance with service standards are met at the highest levels. 


\section{Contract Modification for Performance Using Contractual Authority and In-house Cost Analysis}

In May 2011, a transit authority issued a cure notice to a contractor for customer complaints and in-service on-time performance (ISOTP). After the initial cure notice, authority staff identified additional deficiencies that resulted in a material breach of contract. In January 2012, an extension of the original cure notice was sent to the contractor, and the authority exercised its right to partially terminate the contract for a specific bus line for cause in May 2012, and exercised its contractual authority to permanently transfer the line from the current contractor to another contractor that was already operating adjacent lines. Authority staff considered bringing the services in-house for the remaining three years of the contract period; however, based on the authority's marginal cost of $\$ 102$ per revenue service hour, the cost to operate the line in-house was projected at $\$ 10$ million compared to the contractor's cost of $\$ 7.3$ million. Under existing contract modification authority, the other contractor's contract was modified to include operation of the specific line through December 2012. This contract modification extended the contractor's operation of the line through December 2015 and added funds to the contract for the contract period.

\section{Internal Audit of Contractor Compliance}

An internal audit at a transit agency was conducted in 2011 to review the execution and monitoring of the contractor's fixed route purchased services contract. The audit focused on operational areas identified as having the greatest probability for needing improvement. The audit objective was to determine whether the contractor was in compliance with contract terms, and focused on the following:

- Are contract terms being fulfilled by the contractor?

- Does the contractor's performance align with contract specifications?

- Does the agency provide sufficient oversight and monitoring to ensure that assets are properly maintained by the contractor?

- Does the contract management plan help ensure effective and timely oversight of the contractor's performance?

- Are contract payments, including associated incentives and penalties, accurately calculated and paid?

The audit recommended fixes for all areas, specifically for ensuring effective and timely oversight of the contractor's performance. The agency was required, by August 2012, to develop a standardized contract management plan (CMP) template that will be expanded and refined for all individual contracts.

\section{Unrealized Savings}

A contractor allegedly promised $\$ 10$ million in annual savings by taking over operations of a transit agency. The agency spent $\$ 39.5$ million in 2011 on bus services, down from $\$ 42.1$ million in 2010 , a $\$ 2.6$ million decrease. The agency saved more money $-\$ 1.5$ million (of the $\$ 2.6$ million) - by cutting bus service (14,000 fewer service hours). Cost savings accounted for about $\$ 1.1$ million of the $\$ 2.6$ million. The agency's expenses rose from $\$ 132.3$ to $\$ 132.8$ million, in part due to $\$ 1.4$ million in increased administration costs on the part of the contractor. Promised savings of $\$ 10$ million annually were unrealized. 


\section{Contractor's Safety Performance}

There was an allegation at a transit agency in 2010 that private operators running buses side-by-side with publicly operated buses had a worse safety record. The authority reported 0.8 preventable accidents per 100,000 miles, while the three contractors' preventable accidents per 100,000 miles ranged from 1.4 to 1.9. A May 2013 report indicated that the agency had a major decrease in bus accidents in 2012. The agency reported that new attention to detail and refresher courses were responsible for the 24 percent decrease in accidents in 2012 as compared to 2011.

\section{Transition to Public Management}

\section{Return to Public Management for Cost Savings}

In 2011, after five years, a transit agency did not renew its contract with its current contractor, which served as manager of the entire system. The agency chose to bring the transit system back under public management, and indicated that it will save more than $\$ 50,000$ a year by returning to agency transit administration.

\section{Return to Public Management for Direct Accountability}

In 2008 , the general manager of a transit authority said that greater direct accountability for customer service was a primary reason he recommended that the board neither renew the agency's contract with the current contractor, nor hire any of three other contractors who bid to take over the paratransit service when the current contract expired. Instead, the transit agency decided to take over the service itself, even though the transit authority faced potential conflict with the labor union representing workers, because it was reluctant to hire all of the contractor's employees.

\section{Transition to Public Management for Direct Control over Management Staff and Costs}

The Management Services Subcommittee of the board of a transit authority recommended an immediate transition to in-house management and revision of the scope of the Management Services Agreement (MSA) with the current contractor, which had held the contract for 13 years. The subcommittee identified the following advantages in moving management from a contract to an in-house function:

- Direct control over management staff, including hiring and retention

- Direct information and control over management costs and resulting cost savings

- Elimination of potential disruptions caused by external corporate reorganizations

- Elimination of potential tensions between external corporate goals and agency goals

The board unanimously approved the contract amendment effective July 2013, a year prior to the contract end date. The authority anticipates savings of \$1.0-2.5 million per year. For the first time since its formation 25 years ago, the authority will have in-house employees.

\section{Transition to Public Management for Flexibility in Service Quality and Cost}

In 2013, after 32 years of contracting for bus drivers externally, a transit agency decided to bring the service in-house. A report from city administration revealed that removing the contractor would provide 
the greatest flexibility in service quality and cost factors. The contract with the service provider expired in December 2012 and had been renewed on a month-to-month basis since then. With cash saved from the transition to in-house, the department was able to hire a Transit Planning and Service Design Coordinator, an Operations Manager, and a Coordinator for Operator Development and Recruitment. The director said, "More hands on, and we'll be able to directly incorporate the city's culture and vision to operators better."

\section{Transition to Public Management for Progressive Leadership of the Regional System's Needs}

In November 2000, voters established a transit district along with a transit sales tax. In 2007, another transit agency (established in 1992) was annexed into the district, governed by a board of trustees appointed by the city councils. Service had been contracted for nearly 17 years. On May 29, 2009, after months of research, the board of trustees voted unanimously to take contracted services in-house, effective August 2009. By taking operations and maintenance in-house, the board said it was better positioned to accomplish its vision of providing progressive leadership for the region's transportation needs. The move allows the district to enhance the integration of management and operations, and to streamline the organization so that performance and services to valued riders continue to improve. Three key factors that motivated management to support ending the contract included the following:

1. Having more direct control over the work environment

2. The change in the contracting industry, where previously several contractors competed for the district's business, now only three large competitors remained, which had purchased the smaller companies; this lack of competition led to less focus on the district's goals and more focus on corporate goals

3. The district's ability to attract personnel with the experience necessary to operate services directly

\section{Using Unification to Enhance Cost-Effectiveness and Efficiency}

\section{Unified Operations}

The board of directors of a transit authority approved an action to authorize the CEO to execute a contract with a contractor for fixed route bus operations and maintenance. The action unified bus operations in two cities under a single contract, with the authority directly managing bus operations in the region. Management staffing was streamlined. Economies of scale were realized for purchasing, training, and administrative functions, and equated to lower operating costs as routes were reassigned between the two cities' facilities. A joint scope of work was developed for the contractor bidding process and proposal evaluations. The decision to award was based on the following, and represents a shift from separate operations to a single contractor.

1. Price

2. Integrated operations plan

3. Management team and firm experience

4. Continuous improvement

5. Employee development 
Over a 10-year period, the price proposal for the unified approach was $\$ 36$ million less than the combined costs to operate each entity separately. A four-day strike in August 2013 was ended after the contractor agreed to eliminate from the bus drivers' union contract a clause that would have allowed the contractor to fire employees at will, without giving them an opportunity to appeal the decision.

\section{Consideration of Unified Operations}

Two neighboring counties are considering handing off operations of their transit systems to one private contract. Commissioners told staff to research the idea and create an interlocal agreement for commissioners to review. The counties would still own their own buses and stops, but who hires the drivers, performs daily maintenance, and plans routes could change. Taking a regional approach to transportation could position the counties to receive more federal funding. The counties already collaborate on transportation through a program that allows riders to connect between the agencies' systems without a transfer fee. The counties also operate a couple of joint routes. In August 2013, both counties indicated they are considering an interlocal agreement to operate the bus system as one.

\section{Cost Savings from a Single Agreement}

A new transit agency officially assumed control over another system in 2011 , seven months after it was formed. Contracts for bus service were consolidated in July 2011 under a single agreement with the contractor (the contract with the other system ended June 30,2011). Bus operations were moved to a single base, and the consolidation was expected to save \$1 million over operating systems independently in the first year alone.

\section{Regional Service Meets Service Needs}

Since December 2012, the contractor for a regional transit authority leveraged the locations of two facilities, as opposed to using a more standard, single facility to minimize deadhead. The contractor said the situation is unique because of the demand to commute between two cities, instead of a city center and its suburbs.

\section{Intergovernmental Agreement (IGA) Benefits to an Agency}

In May 2013, a city council report proposed adoption of a resolution authorizing an IGA with another city for the provision of fixed route transit service at a cost of $\$ 1,826,021$. The city council has authorized annual contract change orders to multi-year IGAs with the city since 1983 . The change order was the fourth and final amendment to the original five-year IGA, and covered the period from July 1 , 2013, through June 30, 2014.

The IGA identifies the operation of seven routes, details the city's fixed route transit service costs, and provides a summary of performance from fiscal year (FY) 2010 through projected FY 2014. Funding for fixed route transit services comes from the city's Transportation Privilege Tax, Proposition 400 sales tax, and passenger fares. Fixed route transit service costs and a performance summary from FY 2010 through FY 2014 (estimated) are detailed in the report attached to the resolution. The report confirms that policy implications support City Council Critical Objective C. In terms of community involvement, the IGA conforms to the city's Transportation Master Plan Transit Element, the citizen-adopted General Plan Community Mobility Element, and citizen-adopted Proposition 400. 
The transit service detailed in the agreement is also included in the city's draft FY 2014 budget under the "Transit Contract" line items. Administration of the IGA is part of the transit group's annual workload and requires no additional staffing. The contract cost estimate includes maintenance vehicles and operating supplies. The city maintains all bus stops at an estimated annual cost of $\$ 65,000$. Budgets for express and fixed route bus services are addressed each fiscal year, and funds are available for transit services. The city benefits from continuous service, regional coordination, and the avoidance of frequent procurements.

\section{Labor Issues}

\section{Compensation, Work Rules, and Agency Control}

Under a specific state law, no government agency can hire union employees. The bus system was originally run by an electric and gas company, and drivers and customer-service representatives had formed a union. This posed a problem when control of the bus system passed to a transit authority in 1997. As a condition of receiving federal funds, the authority had to guarantee that workers would keep their collective bargaining rights, so the authority called for private transportation companies to bid on a contract to run the bus fleet. In January 2012, bus drivers voted to authorize a strike as their union entered negotiations with the contractor selected to provide service to the authority. At issue were lack of full compensation when called in to attend meetings, inadequate sick-leave days, unsanitary conditions, forced overtime, and split shifts. Because the drivers were contractor employees, the authority was powerless to avert the strike. American Public Transportation Association (APTA) Vice President for Advocacy Art Guzzetti was quoted as saying, "I don't want to sound like I'm against privatization, but there's no inherent advantage of it. There's nothing about the private-sector manager that makes him a better manager than a public-sector manager ... Of course, if the savings are all, say, in the labor part, then you say all you're doing is competing for the lowest wages, and that's a decision that the local community has to make."

\section{Wage Rates and Turnover}

In 2004, a transit agency asked its contractor to improve bus operators' benefits in hopes of keeping drivers on the job longer. The contractor paid its top drivers only \$14 an hour, and lost 30 of its 56 drivers in one year, causing massive service delays and maintenance issues. The regional system paid its top drivers \$21 an hour.

\section{Work Rules}

Buses returned to service in August 2013 after a compromise ended a four-day strike. The transit authority contractor agreed to eliminate from the bus drivers' contract a clause that would have allowed the contractor to fire employees at will, without giving them an opportunity to appeal the decision.

\section{Wages, Benefits, and Work Rules}

In June 2010, a transit authority awarded a new five-year management and operations contract to a contractor. Sticking points detailed in August 2011 labor negotiations between bus drivers and the contractor pursuant to the new contract are detailed in Table 6. 
Table 6 - Proposed Wages, Benefits, and New Work Rules

\begin{tabular}{|c|c|c|}
\hline Issue & Contractor & Union \\
\hline Vacation & $\begin{array}{l}\text { Gradually eliminate } 2 \text { weeks for future } \\
\text { employees }\end{array}$ & $\begin{array}{l}\text { Maintain current } 5 \text { weeks after } 20 \\
\text { years of service }\end{array}$ \\
\hline Future negotiations & $\begin{array}{l}\text { Discuss company's responsibilities, } \\
\text { including pension payments to } \\
\text { employees after contract ends }\end{array}$ & Written documentation now \\
\hline Sick leave & $\begin{array}{l}\text { Employees earn } 1 / 2 \text { day each month and } \\
\text { eliminate payment after December } 31 \\
\text { for any accrued days; the contractor has } \\
\text { a cap of } 35 \text { days already in effect } \\
\text { company-wide }\end{array}$ & $\begin{array}{l}\text { Earn } 1 \text { day each month; payment } \\
\text { for all accrued days for } \\
\text { employees who retire under old } \\
\text { system; standard part of their } \\
\text { contract for the past } 20 \text { years }\end{array}$ \\
\hline Health insurance premiums & Halve contractor contribution & Remain the same \\
\hline Wages & $\begin{array}{l}\text { No employee pay raises the first year, a } \\
1 / 2 \text { percent raise the second year, and a } 1 \\
\text { percent increase each year for the } \\
\text { following } 3 \text { years-a } 31 / 2 \text { percent } \\
\text { increase over the next } 5 \text { years }\end{array}$ & $\begin{array}{l}\text { A } 1 / 2 \text { percent to } 1 \frac{1}{2} \text { percent raise } \\
\text { for employees in the second and } \\
\text { third years of a } 3 \text {-year contract- } \\
\text { potentially a } 3 \text { percent raise over } \\
3 \text { years }\end{array}$ \\
\hline Part-time employees & As many as 60 & No more than 30 \\
\hline Contract length & 5 years & 3 years \\
\hline
\end{tabular}

\section{Wages, Benefits, and Working Conditions}

A transit agency's bus drivers worked more than a year without a contract. The union's issues with the county included salaries, insurance, sick days, and working conditions. There was a brief strike by the workers in September 2011. In December 2011, the commission voted 3-2 to go against their staff's recommendation by passing up the current contractor in favor of pursuing a contract to manage the system with the second company on their list. In May 2012, the local union filed a grievance against the new contractor, alleging that the contractor had agreed to provide its part-time bus drivers with dental, vision, and life insurance in March. After enrolling those employees for the benefits and providing them for a month, the contractor revoked the benefits without notice. In June 2012, the union and the contractor resolved a variety of grievances that accused the company of revoking benefits, assigning hours, and running holiday bus service without first negotiating with the union or following the labor contract. Union leadership asked the county to take over operation of the mass transit system. The same request had been made the previous year, when commissioners passed a gas tax in an effort to fully fund mass transit. Estimates indicated that it would cost the county an additional $\$ 194,000$ to assume management of the system; however, an operational analysis to determine possible savings associated with such a move has not yet been done.

In September 2013, the local union voted unanimously to allow the executive board of the local union to schedule a strike date; the union objects to the $401(\mathrm{k})$ retirement system and wants to be included in the state's retirement system, along with other county employees. Union members have not received a raise since 2008, and no raise is proposed in the new three-year contract. The chairman of the commission noted that it was his intent to make sure that transit workers had comparable retirement 
and healthcare coverage to county workers. The county's new \$0.04 gas tax for transit begins in January 2014.

\section{Compensation, Work Rules, and Agency Control}

In 1991, a transit agency created a subsidiary to manage its union workers, because state law forbade public employees from engaging in collective bargaining, but federal law required continuation of existing bargaining rights in order to receive federal funds. A new state senate bill required that by September 2012, all union employees be transferred in-house, with workers forfeiting their collective bargaining and striking rights-or, all work would be contracted out, and employees would have the right to negotiate their wages and benefits with their employer. Union workers voted to contract out all work in order to retain their bargaining rights. In August 2011, the board of directors voted unanimously to keep wages and benefits the same for union workers transitioning to a new employer, but said it would not guarantee an equivalent pension plan. Union employees would retain accrued pension benefits, but the current pension plan would not transfer to the new private contractor.

The transit agency approved a new contract for fixed route services beginning in August 2012, and will retain the agency's current 240 administrative employees to manage the agency contracts (five in total). In March 2013, the union reached an agreement with the new contractor effective through September 2015. The agreement contains an immediate 2.1 percent wage hike effective February 17 (first increase since 2011) and additional 2.1 percent raises scheduled for October 2013 and 2014; requires a higher health care contribution from workers; slows step pay increases for employees hired after August 19meaning it will take seven years, instead of five, for new employees to reach the top pay grades; and does not include a two-tiered system where workers' wages are lowered. 


\section{Recommended Course of Action}

\section{Decision to Contract}

A contracting decision tree is illustrated in below. The decision to contract begins with a cost analysis of current operations, including a route level assessment, followed by cost-efficiency strategy development that incorporates input from peer agencies. After considering the agency's operating environment, an agency is prepared to make the contracting decision.

The critical first step in the decision-making process is a detailed cost analysis of the current operation, which includes projected revenue by source-fare box revenue and revenue from other sources; projected expenditures by type-labor, non-labor, and other post-employment benefits; available subsidies by source-dedicated taxes, state and local subsidies; and a comparison of current metrics to peer transit authorities and peer systems that contract service-revenue, expenses, local contribution, subsidy-to-revenue ratio, operating and maintenance costs per revenue hour/mile, and NTD performance metrics.

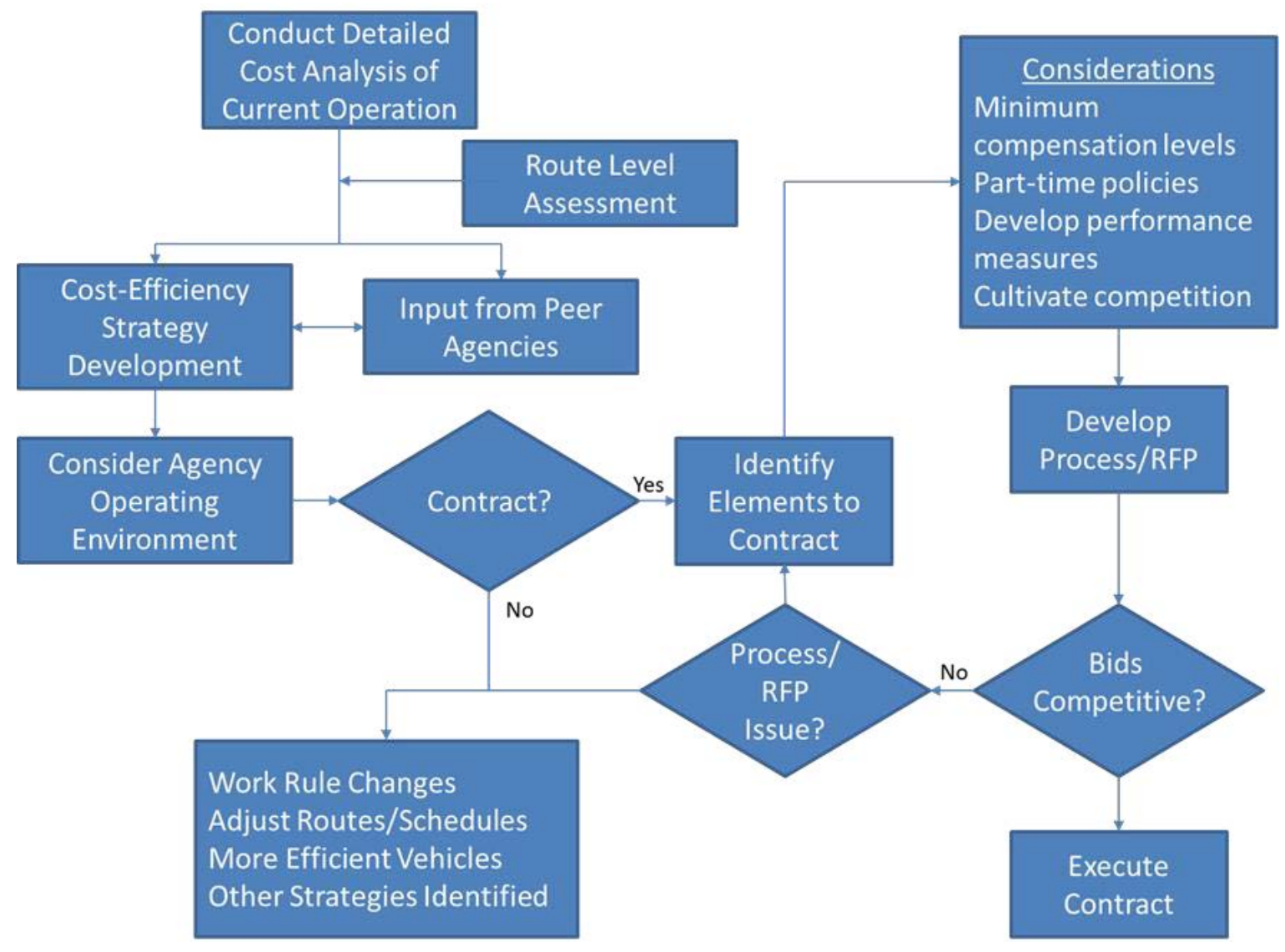

Figure 1 - Contracting Decision Tree

If an agency elects not to contract service, several strategies may help to improve service in-house. An agency can work to change labor agreements related to work rules and compensation. Changes such as 
split shift, interlining, and part-time labor provide managers with more flexibility and reduce costs. Adjusting vehicle routes and scheduling to reduce non-revenue service, and using efficient vehicles appropriately sized for low ridership routes, enhance system effectiveness and reduce costs (Iseki, Ford, and Factor 2006).

If an agency elects to contract service, elements contracted to achieve agency goals must be identified. An agency can consider providing guidelines or setting minimum compensation levels for private sector employees (Iseki, Ford, and Factor 2006); examine private contractors' part-time employee policies and the compensation package structure; and develop measures to evaluate contractor performance and service quality, and arrange to monitor the measures (TRB 2001). An agency can cultivate a competitive bidding environment to reduce the possibility of one contractor monopolizing service provision (McCullough, Taylor, and Wachs 1998).

\section{Procurement - Competitive Process}

An RFP is a competitive procurement method that considers the following:

1. A proposal's management team

2. Approach to service delivery-competitive procedure based on more than cost

3. Past performance

4. Pricing

5. Contractor and key staff reference checks-scrutinize contractors beforehand

The goal of the procurement process is electing a contractor who can be relied upon to provide quality service at a reasonable price. The most common procurement method is competition through an RFP, where the transit agency solicits offers for the service to be provided. Some agencies that use contracting use each of the following methods: (a) orders under pre-existing contracts; (b) sole source or preferred vendors; (c) exercising a contract option (use a provision in an existing contract to extend the term of that contract); and (d) selection from a list of preferred vendors (Arndt and Cherrington 2007).

Agencies that use contracting said they had at least three offers in response to their most recent solicitations for each mode operated, except when obtaining offers for the operation of their commuter rail services (GAO-13-782).

In selecting a contractor, transit agencies may be required to consider potential conflicts of interest. Agencies that use contracting have an ethics policy or standards in place that prohibit conflicts of interest, and they consider federal law, regulations, and guidance prohibiting conflicts of interest for contractor employees and businesses when contracting out (GAO-13-782).

\section{Contract Document}

Contract content is critical to ensuring the procurement process leads to the selection of a qualified, quality contractor. The contract should include the following elements:

1. Outline specific duties/responsibilities for contractor and agency

2. Thorough description of services to be provided 
3. Specify wage rates/cost escalation

4. Support agency will provide

5. Minimum qualifications and experience of the company and key staff

6. Minimum acceptable qualifications for contractor employees (drivers)

7. Established and well-defined service quality performance measures-on-time performance, safety performance, maintenance reliability, and customer satisfaction

8. Established method and frequency of performance measurement

9. Incentive and disincentive clauses tied to performance measures and/or other aspects of contractor's performance (reducing driver turnover)

10. Teamwork/communication with contractor

11. Maintain a cooperative relationship with union

12. Monitor contract performance

13. Process for handling change-amount of service, fuel, changes to key contract staff

(Arndt and Cherrington 2007)

\section{Duration of Contract}

Contract duration impacts the level of competition and quality of service. Potential contractors lose interest in short contract periods due to the cost and effort required to develop a proposal and to start up a new service. Agencies fear long-term contracts produce contractor complacency (Arndt and Cherrington 2007).

While many agencies perceive competition in the bidding process because they receive a large number of initial bids, the long length of existing contracts (on average 5.5 years) and the unequal competition in the bidding process (a few dominant vendors) indicate that adequate competition and innovation is an unlikely result of the current process (Arndt and Cherrington 2007). The most common contract term is a five-year initial contract period, sometimes including the option to extend into additional years (GAO-13-782).

\section{Agency Provision of Equipment - Vehicles}

The transit industry has moved toward providing vehicles and the maintenance facility to the contractor. Primary benefits of the agency providing vehicles include the agency having access to the fleet, which they can operate or re-contract for service in the event of unsatisfactory contractor performance; a bus life of 12 years exceeding most contract periods, forcing the contractor to advance the rate of depreciation as a cost; opening competition to a wider variety of companies since the contractor must be financially able to incur significant debt in the procurement of vehicles; and an agency can take advantage of federal and state grants for procurement (Arndt and Cherrington 2007).

\section{Contract Compensation}

Once a transit agency makes the decision to contract and selects a contractor, the two parties enter into a contract. Among other things, the contract specifies compensation, which may be structured in a variety of ways, including fixed-price compensation, cost-plus compensation, and performance incentives and/or penalties. Fixed-price compensation is based on a set price, with several payment 
options. Payment may be a fixed amount per month. Compensation might also be hourly, meaning the contractor pay is based on the number of hours that service is provided, either the number of hours the transit service collects fares or from the time that vehicles leave the facility until they return. Finally, the contractor can be compensated on a per-trip or per-mile basis, wherein the transit agency pays based on the number of trips provided or miles travelled. Under a cost-plus compensation arrangement, the transit agency reimburses the contractor for all direct transit agency costs, and pays the contractor a fee in the form a flat rate per period of time or a percentage of total direct costs.

The GAO study lists various ways that transit agencies structure compensation in their contracts, including fixed price, price per revenue service based on hours or miles, price per vehicle miles or hours, and number of passenger trips provided.

\section{Managing Contract Services}

Contract services require a level of oversight not unlike directly operated services. Balancing collaboration and oversight is a hallmark of successful contracting. Arndt and Cherrington (2007) suggest the transit agency be prepared to do the following:

- Dedicate some level of staff to manage the service

- Measure performance

- Document service issues

- Monitor maintenance records

- Monitor contractor's safety and training initiatives

- Periodically review accident reports

- Affirm that contractor employees meet contractual standards, where applicable

- Maintain open and amicable communication with contractor to facilitate service improvements, if needed

In the GAO study, transit agencies reported undertaking a variety of activities to assess the quality of contracted services. The most commonly used methods included the following:

- Periodic reports or meetings

- On-site inspections

- Use of performance metrics

- Real-time monitoring

A number of agencies that contract services also reported in the study having a specific unit or department to conduct oversight. Transit agency officials interviewed described how they use various methods, arrangements, and metrics to oversee contractor performance, as listed below:

- Officials that use contractors oversee performance through activities such as routinely communicating with their contractors, either through periodic meetings or as needed; inspecting contractors' facilities or vehicles; and/or using real-time monitoring devices installed on vehicles. 
- Agencies use in-house and third-party contractors to monitor the contractor's performance staff for more high-level oversight and management.

- Agencies that contract some or all of their transit services use metrics to establish performance incentives and/or penalties in contracts. Some agencies do not include performance incentives in their contracts because they expect the contractor to perform at a high level of service; however, they do have penalties for certain violations, such as accidents. 


\section{References}

Arndt, Jeffrey C., and Linda K. Cherrington. 2007. The Role of Private-for-Hire Vehicles in Transit in Texas. College Station, TX: Texas Transportation Institute, The Texas A\&M University System. Accessed November 12, 2013. http://d2dt15nnlpfrOr.cloudfront.net/tti.tamu.edu/documents/0-5545-1.pdf.

Iseki, Hiroyuki, Amy Ford, and Rachel J. Factor. 2006. "Contracting Practice in Fixed-Route Transit Service: Case Studies in California." Transportation Research Record: Journal of the Transportation Research Board 1927: 82-91. Washington, D.C.: Transportation Research Board.

Iseki, Hiroyuki. 2010. "Effects of contracting on cost efficiency in U.S. fixed-route bus transit service." Transportation Research Part A: Policy and Practice 44 (7): 457-472. New Orleans, LA: Elsevier Ltd.

Kim, Songju. 2005. The Effects of Fixed-route Transit Service Contracting on Labor. Dissertation, Department of Civil Engineering, University of California, Berkeley.

Leland, Suzanne, and Olga Smirnova. 2009. "Understanding Local Government's Decision to Contract Out for Transit." A Paper Prepared for the Annual Association for Budgeting and Financial Management Meeting, Washington, D.C. Accessed November 12, 2013. http://coppfs1.asu.edu/spa/abfm2009/papers/PBFOct27.4.pdf

McCullough, William Shelton, III, Brian D. Taylor, and Martin Wachs. 1998. "Transit Service Contracting and Cost-Efficiency." Transportation Research Record 1618: 69-77. Washington, D.C.: Transportation Research Board.

Transportation Research Board (TRB). 2001. Special Report 258, Contracting for Bus and DemandResponsive Transit Services: A Survey of U.S. Practices and Experience. Washington, D.C.: National Academy Press. Accessed November 12, 2013. http://onlinepubs.trb.org/onlinepubs/sr/sr258.pdf

United States Government Accountability Office. 2013. Report to Congressional Committees, Public Transit: Transit Agencies' Use of Contracting to Provide Service, GAO-13-782. Accessed November 12, 2013. http://www.gao.gov/assets/660/658171.pdf.

Wachs, Martin, Karen Trapenberg Frick, and Brian Taylor. 2008. "Contracting for Public Transit Services in the US: Evaluating the Tradeoffs." OECD/ITF, Privatisation and Regulation of Urban Transit Systems: Round Table 141. OECD Publishing. Accessed November 12, 2013. http://www.internationaltransportforum.org/Pub/pdf/08rt141.pdf.

Zullo, Roland. 2008. "Transit Contracting Reexamined: Determinants of Cost Efficiency and Resource Allocation." Journal of Public Administration Research and Theory 18 (3): 495-515. New York, NY: Oxford University Press. 


\section{Appendix A - Contract Review}

\begin{tabular}{|c|c|c|c|c|c|}
\hline Type of Contract & Transit Services Agreement & $\begin{array}{l}\text { Delegated Management } \\
\text { Agreement }\end{array}$ & $\begin{array}{l}\text { Management \& Operations } \\
\text { of Public Transportation } \\
\text { Services Agreement }\end{array}$ & $\begin{array}{l}\text { Delegated Management } \\
\text { Agreement }\end{array}$ & Transit Management \\
\hline Contractor & Independent contractor & Independent contractor & Independent contractor & Independent contractor & Independent contractor \\
\hline Contract Term & 3 years & 5 years & 3 years & 5 years & 5 years \\
\hline $\begin{array}{l}\text { Renewal/ } \\
\text { Extensions }\end{array}$ & $\begin{array}{l}2 \text { one-year upon mutual } \\
\text { consent of parties, subject } \\
\text { to city council's approval }\end{array}$ & $\begin{array}{l}\text { Option to renew } \\
\text { automatically upon (1) } \\
\text { contractor meeting } \\
\text { performance criteria, and } \\
\text { (2) contractor's significant } \\
\text { investment in the transit } \\
\text { system, or by mutual } \\
\text { consent }\end{array}$ & $\begin{array}{l}\text { No reference to renewal or } \\
\text { extension }\end{array}$ & $\begin{array}{l}\text { 5-year renewal at County's } \\
\text { discretion }\end{array}$ & $\begin{array}{l}\text { 2-year extension upon } \\
\text { mutual consent of parties }\end{array}$ \\
\hline Services & $\begin{array}{l}\text { Fixed route operations, } \\
\text { administrative and } \\
\text { maintenance-related } \\
\text { functions }\end{array}$ & $\begin{array}{l}\text { Manage all transit system } \\
\text { functional responsibilities, } \\
\text { operations, and } \\
\text { maintenance }\end{array}$ & Manage and operate & Manage and operate & $\begin{array}{l}\text { Manage, operate, and } \\
\text { maintain }\end{array}$ \\
\hline Revenue Vehicles & $\begin{array}{l}\text { City provides after joint } \\
\text { inspection }\end{array}$ & $\begin{array}{l}\text { Agency delegates to } \\
\text { contractor after joint } \\
\text { inspection }\end{array}$ & $\begin{array}{l}\text { Agency provides after joint } \\
\text { inspection }\end{array}$ & $\begin{array}{l}\text { County licensed contractor } \\
\text { to use County-owned } \\
\text { transit system property }\end{array}$ & County provides \\
\hline $\begin{array}{l}\text { Non-revenue } \\
\text { Vehicles }\end{array}$ & & Contractor responsible & & $\begin{array}{l}\text { Cost to maintain during } \\
\text { first budget year may not } \\
\text { exceed } \$ 20 k\end{array}$ & \\
\hline Facilities & $\begin{array}{l}\text { City provides access to its } \\
\text { transit and maintenance } \\
\text { facilities }\end{array}$ & $\begin{array}{l}\text { Agency delegates to } \\
\text { contractor }\end{array}$ & Agency provides & $\begin{array}{l}\text { County licensed contractor } \\
\text { to use all County-owned } \\
\text { transit system property }\end{array}$ & $\begin{array}{l}\text { County provides and } \\
\text { maintains }\end{array}$ \\
\hline Service Plan & $\begin{array}{l}\text { City provides and reserves } \\
\text { right to adjust }\end{array}$ & $\begin{array}{l}\text { Contractor develops } \\
\text { schedules and routing, } \\
\text { subject to agency approval }\end{array}$ & $\begin{array}{l}\text { Agency provides and } \\
\text { reserves right to adjust to } \\
\text { meet agency's needs }\end{array}$ & $\begin{array}{l}\text { Contractor provides, } \\
\text { subject to Transit } \\
\text { Committee approval }\end{array}$ & $\begin{array}{l}\text { Contractor, but County } \\
\text { may adjust in writing }\end{array}$ \\
\hline
\end{tabular}




\begin{tabular}{|c|c|c|c|c|c|}
\hline Type of Contract & Transit Services Agreement & $\begin{array}{l}\text { Delegated Management } \\
\text { Agreement }\end{array}$ & $\begin{array}{l}\text { Management \& Operations } \\
\text { of Public Transportation } \\
\text { Services Agreement }\end{array}$ & $\begin{array}{l}\text { Delegated Management } \\
\text { Agreement }\end{array}$ & Transit Management \\
\hline Unit Cost & $\begin{array}{l}\text { Renegotiate if revenue } \\
\text { hours }<90 \% \text { or }>110 \%\end{array}$ & $\begin{array}{l}\text { Agency and contractor } \\
\text { negotiated fixed fee } \\
\text { (adjusted annually) and } \\
\text { variable fee (based on } \\
\text { platform hour rate), } \\
\text { pursuant to annual plan } \\
\text { and budget }\end{array}$ & $\begin{array}{l}\text { Renegotiate rate if revenue } \\
\text { hours increase or decrease } \\
\text { by more than } 10 \%\end{array}$ & $\begin{array}{l}\text { County and contractor } \\
\text { negotiated fixed fee } \\
\text { (adjusted annually) and } \\
\text { variable fee (based on } \\
\text { platform hour rate), } \\
\text { pursuant to annual plan } \\
\text { and budget }\end{array}$ & $\begin{array}{l}\text { Contractor may } \\
\text { recommend rate } \\
\text { adjustment to cover } \\
\text { increases or decreases in } \\
\text { cost structure }\end{array}$ \\
\hline Cost Increase & $\begin{array}{l}\text { Annual increase may not } \\
\text { exceed } 3 \% \text { based on CPI in } \\
\text { the MSA }\end{array}$ & & & & $\begin{array}{l}\text { Contractor may submit } \\
\text { proposal for increase in the } \\
\text { case of extraordinary } \\
\text { events }\end{array}$ \\
\hline Fare Policy & $\begin{array}{l}\text { City provides and reserves } \\
\text { right to adjust at City's sole } \\
\text { discretion }\end{array}$ & $\begin{array}{l}\text { Contractor recommends, } \\
\text { subject to agency approval }\end{array}$ & $\begin{array}{l}\text { Agency provides and } \\
\text { reserves right to adjust to } \\
\text { meet agency needs }\end{array}$ & $\begin{array}{l}\text { Contractor provides, } \\
\text { subject to Transit } \\
\text { Committee approval }\end{array}$ & $\begin{array}{l}\text { Contractor provides, but } \\
\text { County may adjust in } \\
\text { writing }\end{array}$ \\
\hline Hours of Service & $\begin{array}{l}\text { City provides and reserves } \\
\text { right to adjust at City's sole } \\
\text { discretion }\end{array}$ & $\begin{array}{l}\text { Contractor recommends, } \\
\text { subject to agency approval }\end{array}$ & $\begin{array}{l}\text { Agency provides and } \\
\text { reserves right to adjust to } \\
\text { meet agency needs }\end{array}$ & $\begin{array}{l}\text { Contractor provides, } \\
\text { subject to Transit } \\
\text { Committee approval }\end{array}$ & $\begin{array}{l}\text { Contractor provides, but } \\
\text { County may adjust in } \\
\text { writing }\end{array}$ \\
\hline $\begin{array}{l}\text { Contract } \\
\text { Compliance }\end{array}$ & $\begin{array}{l}\text { Project manager; City } \\
\text { representatives ride City- } \\
\text { operated vehicles without } \\
\text { notice }\end{array}$ & Authority Board oversight & $\begin{array}{l}\text { Agency Department of } \\
\text { Transit Administration } \\
\text { (Manager) }\end{array}$ & County & $\begin{array}{l}\text { County administrator or } \\
\text { designated representative }\end{array}$ \\
\hline $\begin{array}{l}\text { Equipment } \\
\text { Condition }\end{array}$ & $\begin{array}{l}\text { Contractor responsible; City } \\
\text { issues specific } \\
\text { requirements }\end{array}$ & Contractor responsible & $\begin{array}{l}\text { Contractor responsible; } \\
\text { agency issues specific } \\
\text { requirements }\end{array}$ & Contractor responsible & $\begin{array}{l}\text { Contractor responsible; } \\
\text { County specifies minimum } \\
\text { requirements }\end{array}$ \\
\hline $\begin{array}{l}\text { Vehicle } \\
\text { Maintenance }\end{array}$ & $\begin{array}{l}\text { City provided until } \\
\text { renegotiated in July 2010; } \\
\text { contractor now provides for } \\
\text { fixed monthly fee }\end{array}$ & Contractor provides & $\begin{array}{l}\text { Contractor provides; } \\
\text { agency issues specific } \\
\text { requirements; contractor } \\
\text { must purchase parts off } \\
\text { agency accounts with } \\
\text { suppliers for agency- } \\
\text { owned vehicles }\end{array}$ & $\begin{array}{l}\text { Contractor must provide } \\
\text { written maintenance plan }\end{array}$ & $\begin{array}{l}\text { Contractor provides, but } \\
\text { County specifies minimum } \\
\text { requirements }\end{array}$ \\
\hline Fuel & City provides & Agency provides & $\begin{array}{l}\text { Agency fuel adjustment } \\
\text { quarterly }\end{array}$ & Contractor provides & Contractor provides \\
\hline
\end{tabular}




\begin{tabular}{|c|c|c|c|c|c|}
\hline Type of Contract & Transit Services Agreement & $\begin{array}{l}\text { Delegated Management } \\
\text { Agreement }\end{array}$ & $\begin{array}{l}\text { Management \& Operations } \\
\text { of Public Transportation } \\
\text { Services Agreement }\end{array}$ & $\begin{array}{l}\text { Delegated Management } \\
\text { Agreement }\end{array}$ & Transit Management \\
\hline Drivers & $\begin{array}{l}\text { Contractor provides; City } \\
\text { issues specific } \\
\text { requirements }\end{array}$ & Contractor provides & $\begin{array}{l}\text { Contractor provides; } \\
\text { agency issues specific } \\
\text { requirements }\end{array}$ & $\begin{array}{l}\text { Contractor provides; } \\
\text { County provides specific } \\
\text { requirements }\end{array}$ & Contractor provides \\
\hline Supervisors & $\begin{array}{l}\text { Contractor provides; City } \\
\text { issues specific } \\
\text { requirements }\end{array}$ & Contractor provides & $\begin{array}{l}\text { Contractor provides; } \\
\text { agency issues specific } \\
\text { requirements }\end{array}$ & Contractor provides & Contractor provides \\
\hline Personnel & $\begin{array}{l}\text { Contractor provides for all } \\
\text { classifications }\end{array}$ & $\begin{array}{l}\text { Contractor provides for all } \\
\text { classifications }\end{array}$ & $\begin{array}{l}\text { Contractor provides for all } \\
\text { classifications }\end{array}$ & $\begin{array}{l}\text { Contractor provides for all } \\
\text { classifications }\end{array}$ & $\begin{array}{l}\text { Contractor provides for all } \\
\text { classifications; } \\
\text { employment preference to } \\
\text { local labor }\end{array}$ \\
\hline $\begin{array}{l}\text { Mandatory } \\
\text { Personnel }\end{array}$ & $\begin{array}{l}\text { Project manager, mechanic, } \\
\text { half-time road supervisor, } \\
\text { general manager }\end{array}$ & $\begin{array}{l}\text { CEO, CFO, COO, chief } \\
\text { maintenance officer, } \\
\text { marketing director, HR } \\
\text { director, director } \\
\text { scheduling/planning, } \\
\text { director of procurement, } \\
\text { executive consulting } \\
\text { personnel, technical } \\
\text { assistance }\end{array}$ & $\begin{array}{l}\text { Project manager, } \\
\text { maintenance manager; } \\
\text { agency issues specific } \\
\text { requirements }\end{array}$ & CEO and $\mathrm{COO}$ & $\begin{array}{l}\text { General manager, subject } \\
\text { to County approval }\end{array}$ \\
\hline $\begin{array}{l}\text { Labor } \\
\text { Negotiations }\end{array}$ & Contractor responsible & Contractor responsible & Contractor responsible & Contractor responsible & $\begin{array}{l}\text { Contractor responsible and } \\
\text { must notify County of ATU } \\
\text { employee wage rate } \\
\text { modifications }\end{array}$ \\
\hline Training & $\begin{array}{l}\text { Contractor provides; City } \\
\text { issues specific } \\
\text { requirements }\end{array}$ & Contractor provides & $\begin{array}{l}\text { Contractor provides; } \\
\text { agency issues specific } \\
\text { requirements }\end{array}$ & Contractor provides & Contractor provides \\
\hline $\begin{array}{l}\text { Fare Collection \& } \\
\text { Reconciliation }\end{array}$ & $\begin{array}{l}\text { Contractor responsible; } \\
\text { reports to City monthly } \\
\text { by day }\end{array}$ & Contractor responsible & Contractor responsible & $\begin{array}{l}\text { Contractor responsible for } \\
\text { collection and } \\
\text { reconciliation; County } \\
\text { provides specific } \\
\text { requirements }\end{array}$ & Contractor responsible \\
\hline
\end{tabular}




\begin{tabular}{|c|c|c|c|c|c|}
\hline Type of Contract & Transit Services Agreement & $\begin{array}{l}\text { Delegated Management } \\
\text { Agreement }\end{array}$ & $\begin{array}{l}\text { Management \& Operations } \\
\text { of Public Transportation } \\
\text { Services Agreement }\end{array}$ & $\begin{array}{l}\text { Delegated Management } \\
\text { Agreement }\end{array}$ & Transit Management \\
\hline $\begin{array}{l}\text { Fare Box } \\
\text { Recovery }\end{array}$ & $\begin{array}{l}\text { Contractor must satisfy } \\
\text { Transportation } \\
\text { Development Act } \\
\text { requirement that } 15 \% \text { of } \\
\text { monthly operating cost is } \\
\text { obtained from fare box } \\
\text { revenue for fixed route; any } \\
\text { shortfall in the } 15 \% \text { must be } \\
\text { paid by the contractor at } \\
\text { the end of the year }\end{array}$ & $\begin{array}{l}\text { No liability for revenue } \\
\text { shortages }\end{array}$ & $\begin{array}{l}\text { Agency requires } 100 \% \\
\text { collection from fare boxes }\end{array}$ & $\begin{array}{l}\text { Beginning with second } \\
\text { budget year, if fare box } \\
\text { revenue falls short of } \\
\text { annual or exceeds } \\
\text { projected revenue, } \\
\text { contractor responsible for } \\
\text { or receives surplus or } \\
\text { shortfall up to } 5 \% \text { of } \\
\text { annual projected fare box } \\
\text { revenue; contractor may } \\
\text { renegotiate financial terms } \\
\text { if shortfall is }>10 \% \text { for } 2 \\
\text { quarters }\end{array}$ & Contractor responsible \\
\hline Safety \& Security & $\begin{array}{l}\text { Contractor provides; City } \\
\text { issues specific } \\
\text { requirements; contractor } \\
\text { must develop and } \\
\text { distribute Illness \& Injury } \\
\text { Prevention Plan }\end{array}$ & Contractor provides & $\begin{array}{l}\text { Contractor provides; } \\
\text { agency issues specific } \\
\text { requirements; contractor } \\
\text { to submit plan to increase } \\
\text { overall traffic at terminal } \\
\text { to improve transit safety } \\
\text { and security }\end{array}$ & Contractor provides & Contractor provides \\
\hline Reporting & $\begin{array}{l}\text { Contractor responsible; City } \\
\text { issues specific } \\
\text { requirements for daily, } \\
\text { weekly, and monthly } \\
\text { reports }\end{array}$ & $\begin{array}{l}\text { Contractor reports } \\
\text { monthly: system } \\
\text { expenditures, financial } \\
\text { and operating records }\end{array}$ & $\begin{array}{l}\text { Contractor responsible; } \\
\text { agency issues specific } \\
\text { requirements for monthly } \\
\text { reports }\end{array}$ & $\begin{array}{l}\text { Contractor responsible, } \\
\text { including Performance } \\
\text { Measures and } \\
\text { Performance Scorecard }\end{array}$ & $\begin{array}{l}\text { County identifies monthly } \\
\text { and annual reporting } \\
\text { requirements }\end{array}$ \\
\hline $\begin{array}{l}\text { FTA/NTD } \\
\text { Reporting }\end{array}$ & Contractor responsible & Contractor responsible & Contractor responsible & Contractor responsible & Contractor responsible \\
\hline $\begin{array}{l}\text { Drug-Free } \\
\text { Workplace }\end{array}$ & Contractor responsible & Contractor responsible & Contractor responsible & Contractor responsible & Contractor responsible \\
\hline $\begin{array}{l}\text { Software \& } \\
\text { Hardware }\end{array}$ & Contractor provides & Contractor provides & Contractor provides & Contractor provides & Contractor provides \\
\hline $\begin{array}{l}\text { Customer } \\
\text { Information } \\
\text { Service }\end{array}$ & $\begin{array}{l}\text { Contractor provides; City } \\
\text { issues specific } \\
\text { requirements }\end{array}$ & Contractor provides & Contractor provides & Contractor provides & Contractor provides \\
\hline
\end{tabular}




\begin{tabular}{|c|c|c|c|c|c|}
\hline Type of Contract & Transit Services Agreement & $\begin{array}{l}\text { Delegated Management } \\
\text { Agreement }\end{array}$ & $\begin{array}{l}\text { Management \& Operations } \\
\text { of Public Transportation } \\
\text { Services Agreement }\end{array}$ & $\begin{array}{l}\text { Delegated Management } \\
\text { Agreement }\end{array}$ & Transit Management \\
\hline Complaints & $\begin{array}{l}\text { Contractor responds; } \\
\text { maintains log; reports to } \\
\text { City as specified }\end{array}$ & Contractor responsible & Contractor responsible & Contractor responsible & $\begin{array}{l}\text { Contractor maintains } \\
\text { Complaint Tracking } \\
\text { Database }\end{array}$ \\
\hline $\begin{array}{l}\text { Marketing \& } \\
\text { Advertising }\end{array}$ & City provides & Contractor provides & Agency provides & Contractor provides & Contractor provides \\
\hline $\begin{array}{l}\text { Operating } \\
\text { Expenses }\end{array}$ & & & $\begin{array}{l}\text { Contractor pays all } \\
\text { operating expenses and } \\
\text { agency will reimburse }\end{array}$ & & $\begin{array}{l}\text { County responsible for } \\
\text { payment of all operating } \\
\text { expenses, but contractor } \\
\text { must retain necessary } \\
\text { working capital equal to } \\
\text { fund at least } 60 \text { days of } \\
\text { operating expenses; } \\
\text { County will pay on a cash } \\
\text { reimbursement basis }\end{array}$ \\
\hline $\begin{array}{l}\text { Liquidated } \\
\text { Damages }\end{array}$ & $\begin{array}{l}\text { Contractor charged each } \\
\text { time default occurs: } \$ 100 \\
\text { per non-trainee driver's } \\
\text { failure to wear an approved } \\
\text { uniform while on duty; } \$ 50 \\
\text { per trip for driver's failure } \\
\text { to announce major } \\
\text { intersections, transfer } \\
\text { opportunities, and major } \\
\text { activities as required by } \\
\text { ADA; } \$ 50 \text { per missed trip } \\
\text { that was in contractor's } \\
\text { control; maximum } \\
\text { liquidated damages in any } \\
\text { month must not exceed } \\
\$ 1,000\end{array}$ & No liquidated damages & $\begin{array}{l}\$ 100 \text { per day will begin to } \\
\text { accrue and payable on the } \\
16^{\text {th }} \text { day of each month } \\
\text { until the manager receives } \\
\text { monthly reports; } \$ 100 \text { per } \\
\text { day per vehicle assessed } \\
\text { against monthly invoice for } \\
\text { vehicles reported as dirty } \\
\text { for } 2 \text { consecutive days, } \\
\text { inoperable air conditioning } \\
\text { and heating longer than } \\
\text { same day of breakdown, } \\
\text { operating vehicles that } \\
\text { have failed the safety } \\
\text { inspection; and } \$ 5,000 \text { for } \\
\text { each event of false or } \\
\text { misleading information } \\
\text { given to the agency for any } \\
\text { instance as delineated in } \\
\text { agreement }\end{array}$ & $\begin{array}{l}\text { Contractor must pay } \\
\$ 5,000 \text { for } 5 \text { percentage } \\
\text { points worse than } \\
\text { benchmark for on-time } \\
\text { performance; } \$ 2,000 \text { for } 5 \\
\text { percentage points worse } \\
\text { than benchmark for } \\
\text { percentage of missed } \\
\text { pullouts; and } \$ 5,000 \text { for } \\
10 \% \text { worse than the } \\
\text { benchmark for accidents } \\
\text { per } 100,000 \text { miles }\end{array}$ & \\
\hline
\end{tabular}




\begin{tabular}{|c|c|c|c|c|c|}
\hline Type of Contract & Transit Services Agreement & $\begin{array}{l}\text { Delegated Management } \\
\text { Agreement }\end{array}$ & $\begin{array}{l}\text { Management \& Operations } \\
\text { of Public Transportation } \\
\text { Services Agreement }\end{array}$ & $\begin{array}{l}\text { Delegated Management } \\
\text { Agreement }\end{array}$ & Transit Management \\
\hline Incentives & $\begin{array}{l}\text { May earn up to } \$ 500 \text { per } \\
\text { quarter for increased } \\
\text { ridership of }>10 \% \text { over the } \\
\text { past } 2 \text { quarters average }\end{array}$ & & & & \\
\hline $\begin{array}{l}\text { Performance } \\
\text { Measures }\end{array}$ & $\begin{array}{l}\text { Reported monthly by } \\
\text { contractor: miles between } \\
\text { road calls; miles between } \\
\text { maintenance road calls; \# } \\
\text { and \% of missed/late pull- } \\
\text { outs; \# and \% of } \\
\text { missed/late trips; \# and \% } \\
\text { of on-time performance; \# } \\
\text { of complaints/1,000 } \\
\text { passengers; total accidents/ } \\
100,000 \text { miles; collision } \\
\text { accidents/100,000 miles; } \\
\text { ridership by day, mode, } \\
\text { route, and fare type; total } \\
\text { preventable accidents/ } \\
100,000 \text { miles; passenger } \\
\text { accidents/100,000 miles; } \\
\text { pass sales activity at } \\
\text { dispatch office; wheelchair } \\
\text { boardings; drug \& alcohol } \\
\text { tests; driver/dispatcher } \\
\text { training activities; driver } \\
\text { evaluations; and request } \\
\text { for service not currently } \\
\text { provided }\end{array}$ & $\begin{array}{l}\text { Invest in in-house } \\
\text { technical resources for } \\
\text { development/financing of } \\
\text { creation/expansion of rail } \\
\text { systems; strive to improve } \\
\text { operating performance for } \\
\text { safety (current } \\
\text { preventable traffic } \\
\text { accident frequency: bus } \\
2.0, \text { streetcar 5.06), } \\
\text { on-time service (current: } \\
\text { bus } 88 \% \text {, streetcar } 85 \% \text { ); } \\
\text { and passenger growth } \\
\text { (current: bus } 19 \text { per hour, } \\
\text { streetcar } 37 \text { per hour); } \\
\text { invest in agency's } \\
\text { infrastructure; provide } \\
\text { services to seek public } \\
\text { funding at local, state, and } \\
\text { federal levels; provide a } \\
\text { national Emergency } \\
\text { Response Team in the } \\
\text { event of a natural } \\
\text { disaster; and seek to } \\
\text { reduce } \$ 151.17 \text { operating } \\
\text { cost per hour by } 25 \% \\
\text { throughout contract term } \\
\text { (adjusted for inflation) }\end{array}$ & $\begin{array}{l}\text { Contractor must submit } \\
\text { implementation plan to } \\
\text { increase ridership at least } \\
10 \% \text { within first year of } \\
\text { agreement }\end{array}$ & $\begin{array}{l}\text { Performance Scorecard: } \\
\text { revenue hours; service } \\
\text { miles operated; cost per } \\
\text { mile; revenue per mile; } \\
\text { cost recovery; \% of miles } \\
\text { @ } 100 \% \text { recovery; calls } \\
\text { answered ratio; pass-ups; } \\
\text { on-time \%; customer } \\
\text { satisfaction score; net } \\
\text { promoter score; missed } \\
\text { trips; mechanical } \\
\text { breakdowns per week; and } \\
\text { accidents per 100,000 } \\
\text { miles. Bus cleanliness, stop } \\
\text { cleanliness, and on-time } \\
\text { perception were listed as } \\
\text { tentative and subject to } \\
\text { modification or } \\
\text { replacement. }\end{array}$ & $\begin{array}{l}\text { Contractor must certify } \\
\text { quarterly on-time } \\
\text { performance of at least } \\
90 \% \text {; implement Rider } \\
\text { Technology within } 3 \\
\text { months; establish and } \\
\text { maintain a GIS layer for all } \\
\text { routes, stops, benches, and } \\
\text { shelters within } 6 \text { months; } \\
\text { and implement Escambia } \\
\text { County TDP within } 6 \\
\text { months; contractor will } \\
\text { periodically propose } \\
\text { alternatives for poor- } \\
\text { performing routes, subject } \\
\text { to County approval }\end{array}$ \\
\hline
\end{tabular}




\begin{tabular}{|c|c|c|c|c|c|}
\hline \multicolumn{6}{|c|}{ Payment Schedule - Fixed Route Bus Service } \\
\hline $\begin{array}{l}\text { Method of } \\
\text { Payment }\end{array}$ & Transit Services Agreement & $\begin{array}{c}\text { Delegated Management } \\
\text { Agreement }\end{array}$ & $\begin{array}{c}\text { Management \& } \\
\text { Operations of Public } \\
\text { Transportation Services } \\
\text { Agreement }\end{array}$ & $\begin{array}{c}\text { Delegated Management } \\
\text { Agreement }\end{array}$ & Transit Management \\
\hline $\begin{array}{l}\text { Monthly Fixed } \\
\text { Fee }\end{array}$ & $\$ 14,738$ & $\$ 1,390,732 *$ & & $\$ 2,319,664$ & $\$ 32,750$ \\
\hline $\begin{array}{l}\text { Revenue Hour } \\
\text { Rate }\end{array}$ & $\$ 29.47$ & & $\$ 100.73$ & & \\
\hline $\begin{array}{c}\text { Projected } \\
\text { Revenue Hours }\end{array}$ & 5,366 & & 98,150 & & \\
\hline $\begin{array}{l}\text { Maintenance } \\
\text { Monthly Fixed } \\
\text { Fee }\end{array}$ & $\$ 2,500$ & & & & \\
\hline $\begin{array}{c}\text { Monthly Variable } \\
\text { Fee }\end{array}$ & & $\$ 76.86$ & & $\$ 87.12$ & \\
\hline $\begin{array}{c}\text { Projected } \\
\text { Platform Hours }\end{array}$ & & 299,388 & & & \\
\hline $\begin{array}{l}\text { Projected Annual } \\
\text { Cost }\end{array}$ & $\$ 365,000$ & & $\$ 9,886,650$ & & $\$ 393,000+$ \\
\hline Adjustments & & $\begin{array}{l}\text { Monthly fixed fee adjusted } \\
\text { annually }\end{array}$ & $\begin{array}{l}\text { Renegotiate revenue hour } \\
\text { rate if revenue hours } \\
\text { increase or decrease by } \\
>10 \%\end{array}$ & $\begin{array}{c}\text { Fixed fee adjusted } \\
\text { annually; variable fee } \\
\text { adjusted annually based } \\
\text { on CPI, special } \\
\text { circumstances, and } \\
\text { reasonable profit for } \\
\text { contractor }\end{array}$ & $\begin{array}{c}\text { Cash reimbursement of all } \\
\text { operating expenses }\end{array}$ \\
\hline
\end{tabular}

*Includes fixed route, streetcar rail, and paratransit service. 